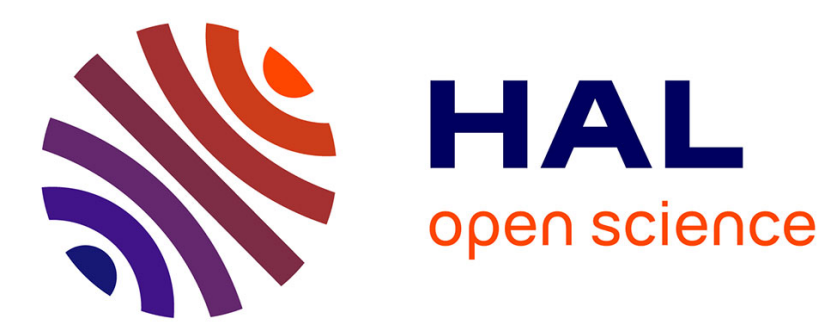

\title{
Policy Instruments, Patents and International Technology Diffusion in a North-South Duopoly
}

Julien Berthoumieu

\section{To cite this version:}

Julien Berthoumieu. Policy Instruments, Patents and International Technology Diffusion in a NorthSouth Duopoly. 2015. hal-01155111

\section{HAL Id: hal-01155111 \\ https://hal.science/hal-01155111}

Preprint submitted on 26 May 2015

HAL is a multi-disciplinary open access archive for the deposit and dissemination of scientific research documents, whether they are published or not. The documents may come from teaching and research institutions in France or abroad, or from public or private research centers.
L'archive ouverte pluridisciplinaire HAL, est destinée au dépôt et à la diffusion de documents scientifiques de niveau recherche, publiés ou non, émanant des établissements d'enseignement et de recherche français ou étrangers, des laboratoires publics ou privés. 


\section{Grefliworking Paper \\ Laboratoire d'Analyse et de ReCherche en Économie et Finance Internationales \\ Policy Instruments, Patents and International Technology Diffusion in a North-South Duopoly}

Julien Berthoumieu

LAREFI Working Paper N²015-02

2015

http://lare-efi.u-bordeaux4.fr

LAREFI

Université de Bordeaux

Bâtiment Recherche Economie $-1^{\text {er }}$ étage

Avenue Léon Duguit - 33608 Pessac 


\section{LAREFI - LABORATOIRE D'ANALYSE ET DE RECHERCHE EN ECONOMIE ET FINANCES INTERNATIONALES}

\section{AUTHORS}

Julien Berthoumieu, LAREFI, Université Montesquieu Bordeaux IV

\section{NOTICES}

LAREFI Working Papers contain preliminary material and research results. They have been peer reviewed. They are circulated in order to stimulate discussion and critical comment; any opinions expressed are only those of the author(s).

Copyright LAREFI. All rights reserved. Sections of this material may be reproduced for personal and not-for-profit use without the express written permission of but with acknowledgment to LAREFI. To reproduce the material contained herein for profit or commercial use requires express written permission. To obtain permission, contact LAREFI at cyril.mesmer@u-bordeaux4.fr. 


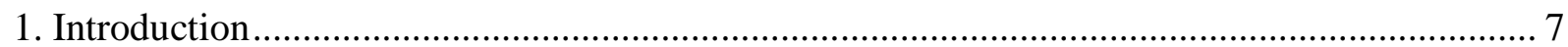

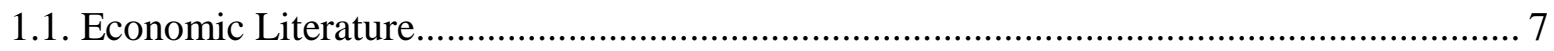

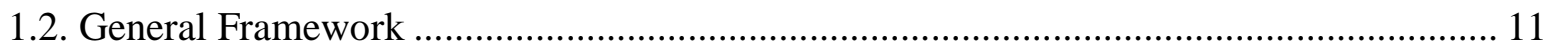

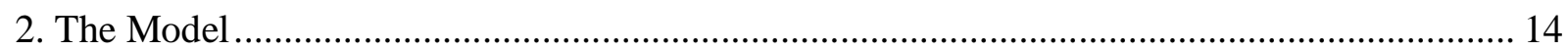

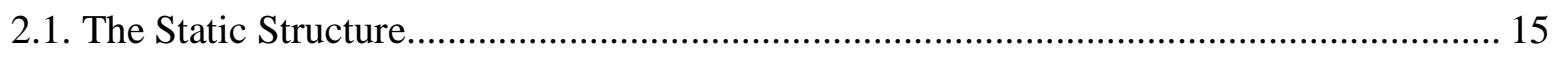

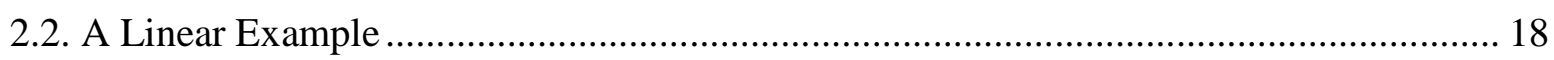

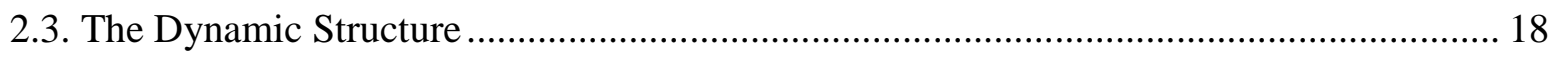

3. The Impact of "Behind-The-Border" Policies Implemented by The Northern Government ... 19

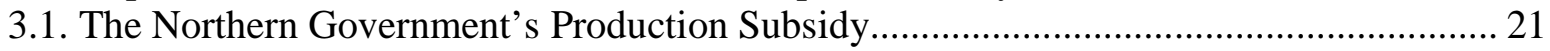

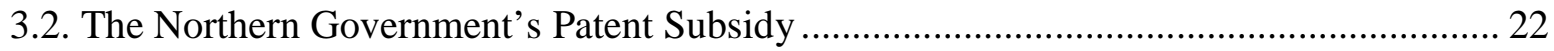

4. The Impact of "Behind-The-Border" Policies Implemented by The Southern Government ... 23

4.1. The Southern Government's Production Subsidy .......................................................... 23

4.2. The Southern Government's Public R\&D Investment/R\&D Subsidy.............................. 24

5. An Example of “At-The-Border” Policies: The Impact of Import Tariffs .............................. 27

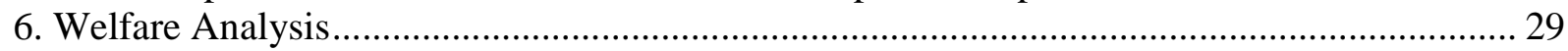

6.1. General Framework Under Free Trade ..................................................................... 29

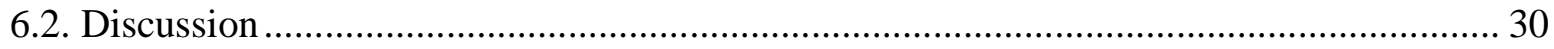

6.3. Optimal Policy Instruments Under Numerical Simulations ........................................ 31

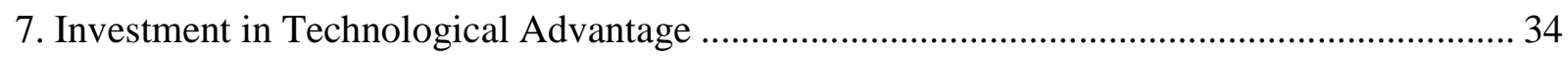

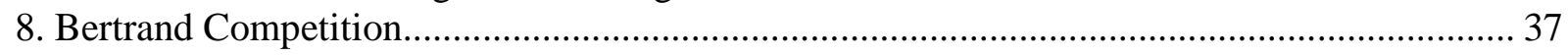

8.1. The Impact of Policy Instruments on The Speed of The New Technology Diffusion ...... 37

8.2. Welfare Analysis With Numerical Simulations Under Bertrand Competition.................. 39

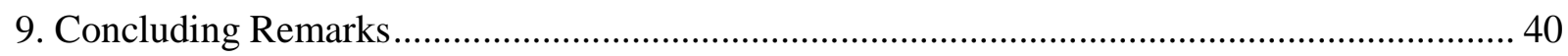




\section{List of tables}

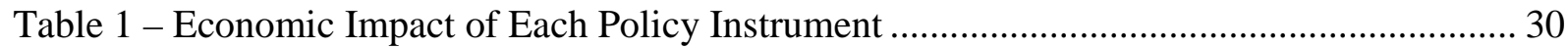

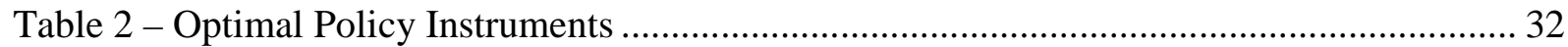

Table 3 - Optimal Policy Instruments Under Bertrand Competition ........................................... 39

Table 4 - Optimal Policy Instruments When Parameters Vary .................................................... 44

Table 5 - Optimal Policy Instruments When Parameters Vary Under Bertrand Competition..... 49 


\section{List of figures}

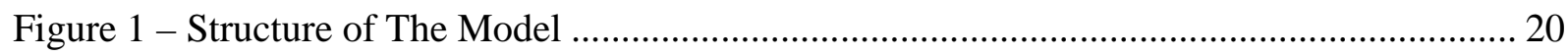

Figure 2 - Evolution of The Optimal Patent Subsidy $\boldsymbol{\varphi}$ When $\boldsymbol{\beta}$ Varies .................................... 36 


\begin{abstract}
This paper analyzes the relationship between public policy instruments and technology diffusion in a North-South duopoly, within an inter-temporal model where time is continuous. Initially, the Northern firm benefits from a new technology while the Southern firm uses only an old technology. There is a monopoly period with the new technology for the Northern firm. At the end, there is then technology diffusion from the Northern firm to the Southern firm. The Northern firm files patent in order to slow down diffusion. This article studies the impact of policy instruments: (i) a production subsidy, a patent subsidy and an import tariff implemented by the Northern country, (ii) a production subsidy, a public Research and Development investment and an import tariff implemented by the Southern country. The results show that the Northern government's policies slow down technology diffusion by increasing the monopoly period with the new technology while the Southern government's policies accelerate it.

Welfare analysis demonstrates that governments are encouraged to implement each policy instrument, except in the case of patent subsidy. The Northern government is encouraged to tax patent expenditures. Nevertheless, the patent subsidy may be optimal if the Northern firm invests in Research and Development due to its technological advantage with the patent.
\end{abstract}

Keywords: Technology Diffusion, Patent, Production Subsidy, Patent Subsidy, Research and Development Investment, Import Tariff.

JEL classification: F13, O33. 
The study of international technology diffusion has become an important aspect of economics. Technology diffusion is a central topic for developing countries because it relates to a development issue. It represents a way to improve industries that enhance economic development, especially those that are capital-intensive. As a matter of fact, modern technology in industries increases workers' wages, purchasing power and standard of living for developing countries. It improves working conditions. Technology diffusion on production processes may also involve product innovations which benefit from the consumers of developing countries. Furthermore, there is now much evidence to support the assumption that public policy instruments like subsidies have an impact on diffusion. But determining the sign of such impact is complex.

Technology diffusion occurs because of information diffusion (Geroski, 2000). With modern telecommunications, information is easily available everywhere. It involves technological spillovers. Keller (2002) says that "telecommunications and the Internet ensure that people in all countries have access to the same pool of technological endowment [p. 120]." As a matter of fact, technology diffusion is not something that can be avoided. Technology may be diffused from developed countries to other developed countries. But it may also be diffused from developed countries to developing countries. Developing countries acquire modern production processes that developed countries previously discovered by innovating. Note that developing countries' innovations expenditures are low. According to Keller (2004), "only a handful of rich countries account for most of the world's creation of new technology. The pattern of worldwide technical change is thus determined in large part by international technology diffusion [p. 752]." Then, developing countries' technological endowment depends on technology diffusion.

\subsection{Economic Literature}

The issue of technology diffusion has been studied in economic literature. Note that Keller (2004) makes a wide survey of economic literature for this topic. A first factor of technology diffusion is Research and Development (R\&D) investment owing to R\&D spillovers, the sources of which we need to find. Generally, the speed of technology diffusion between two countries increases with the 
volume of trade between them, especially the trade of intermediate goods (Rivera-Batiz and Romer,

1991; Grossman and Helpman, 1991; Eaton and Kortum, 2002). Developing countries import intermediate goods from developed countries and need to use modern technology to produce finished goods. Usually, international trade involves information flows between countries because of business interactions. Coe and Helpman (1995) find close results empirically by showing that the R\&D spillovers effect increases with the openness of international trade. Economic literature has also proven that the speed of technology diffusion between two countries increases with Foreign Direct Investments (FDI) stock because of FDI spillovers for the country receiving it (Griliches and Hausman, 1986; Keller, 2002; Griffith, Redding and Simpson, 2003). For example, Japanese R\&D investments in Asian developing economies increased nine-fold from 1993 to 2007 (UNCTAD, 2011). Developing countries like China, Korea or India benefited from such Japanese investments. Multinational Firms (MNF) use labor force from a foreign country where they are located. Spillovers between countries appear because of worker training by MNF (Aitken and Harrisson, 1999; Fosfuri, Motta and Rønde, 2001). This is the reason why the relationship between MNF and subsidiaries located in foreign countries clearly influences FDI (Markusen, 2002). International trade and FDI represent two important factors of technology diffusion. Ethier and Markusen (1996) studies the choice between international trade and FDI for a firm that wishes to sell its product in a foreign country by using a theoretical dynamic framework with technological externalities. A firm from the domestic country discovers a new product and benefits from a temporary monopoly (equal to two periods in the model). The firms from the foreign country do not invest in research in order to discover new products. The firm has a choice between exporting from its domestic country and locating a part of its output in the foreign country. According to the authors, localization involves greater absorption of information for other firms in the foreign country that can produce the new product faster. Then, technology diffusion seems to be faster with localization than with exports. But it represents a cost for the domestic firm because the new product is no longer in a monopoly situation. The choice between exporting and locating depends on the transport cost of exports and the monopoly rent of localization.

Economic literature analyzes the impact of public policies (especially trade policies) on technology diffusion. The reference model without diffusion is the framework of Spencer and 
Brander (1983) which analyzes the positive effect of an R\&D subsidy on domestic R\&D investment and national welfare in an international duopoly. Cheng (1987) designs a close framework within a dynamic model. Considering international technology diffusion, he shows that the R\&D subsidy that only satisfies domestic interest may benefit from the foreign firm. It may also enhance diffusion. Grossman and Helpman (1991) implement a theoretical macroeconomic model with technological spillovers and study the economic impact of trade openness for a small country. They show that trade policies which reduce (respectively promote) international trade, especially trade of intermediate goods, like tariffs or quotas (respectively subsidies) have a negative (respectively positive) effect on innovations and technology diffusion via knowledge spillovers. For example, a tariff cut involves an increase in trade volume, trade through variety of intermediate goods and stock of human capital through variety. Then, spillovers to foreign countries are greater. Miyagiwa and Ohno (1997) design an interesting structure to analyze the impact of subsidies on R\&D and welfare. They use a dynamic theoretical model. Initially, two firms use an old technology. At each point in time, they invest in R\&D to discover a new technology. There is a likelihood of discovering it at each point in time for each firm. When one firm discovers the new technology, it no longer invests in R\&D. But the other firm continues to invest until it, too, discovers the new technology. The former firm benefits from an exogenous monopoly period with the new technology that corresponds to the speed of diffusion. Reppelin-Hill (1999) makes an econometric study of the relationship between trade openness and speed of clean technology diffusion by using the example of the steel industry. He demonstrates that diffusion of clean technology is "faster in countries that have more open trade policy regimes [p. 284]." Geroski (2000) makes a survey of factors of technology diffusion. Information diffusion involves technology diffusion. He suggests that governments can subsidize technological externalities "to promote ... communication ... and to motivate them [p. 621]." Battisti (2008) also uses the example of environment and establishes that technology diffusion is a low process. Governments' policies may increase R\&D investment but "should also look at the adoption and the extent of use of innovations because that is the place where the generation of the benefits from inventions takes place [p. 528]."

Economic literature also studies the impact of other variables that influence the speed of technology diffusion. Geographic distance between two countries has an impact on technology 
diffusion because of its effect on bilateral trade. Generally, previous studies have proven that technology diffusion is faster within one country than between two countries (Jaffe, Traitenberg and Henderson, 1993; Branstetter, 2001; Eaton and Kortum, 1999). There is a border effect. Nevertheless, Irwin and Klenow (1994) find that the speeds of technology diffusion are not significantly different by taking the example of US firms as compared to foreign firms in the semiconductor industry from 1974 to 1992 . Other papers study the significant negative effect of the distance in kilometers on the speed of technology diffusion (Keller, 2002; Bottazi and Peri, 2003).

Furthermore, there is a strong correlation between technology diffusion and industrial protection. For example, a patent has an effect on diffusion because it represents a way to protect information and technological endowment for firms. A patent may slow down technology diffusion by giving a product or process monopoly to firms from developed countries. However, citing patents may be a measure of technology diffusion. Eaton and Kortum (1999) consider that patent filing in a foreign country represents another measure of technology diffusion (even if it is not perfect). They prove that diffusion depends on the possibility to file patents in the foreign country and the patent filing cost that the firm must pay. Pakes (1996) also mentions the role of patent cost when agents want to keep the patent in force. Economic literature has also designed models with patents by studying the impact on national welfare. Such patents may involve a monopoly rent for the firm that files it. Authors have established that patents encourage innovation because a firm has to discover a new process or new product before the patent publication. A first section of literature considers that imitation of competitors is never a threat and identifies the fact that optimal patent length is finite

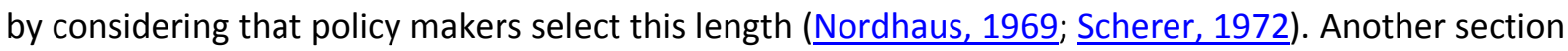
considers that imitation is costless and introduces patent length and breadth (Tandon, 1982; Klemperer, 1990; Gilbert and Shapiro, 1990). According to Gilbert and Shapiro (1990), patent breadth cannot be clearly defined: "a broader patent allows the innovator to earn a higher flow rate of profit during the lifetime of the patent [p. 107]." Even if patent breadth leads to deadweight loss, they demonstrate that optimal patent length is infinite because it minimizes social costs. Gallini (1992) introduces an endogenous imitation cost by considering "the ability of competitors to invent around [p. 52]." He finds that optimal patent length is short in order to avoid imitation. Such a result contrasts with previous studies. Mathew and Mukherjee (2014) study the impact of the patent 
regime on inward FDI in a North-South structure. The incentive of Northern firms' FDI in the

Southern country increases with a strong patent regime, especially when the costs of Southern innovation are high. A strong patent regime corresponds to a situation where only the patent holder can sell its product. Here, the impact of the patent regime on technology diffusion is ambiguous because it may increase FDI inwards in the Southern country, but it may also involve a longer monopoly period for Northern firms relative to the sales of new products.

\subsection{General Framework}

The objective of this paper is to evaluate the impact of policy instruments on technology diffusion by using a simple theoretical framework. We also research the impact on other strategic variables like profits, consumer surplus or national welfares. We use a framework which is close to Miyagiwa and Ohno (1999). But it is a North-South duopoly. We consider a duopoly with one firm from a Northern country and another from a Southern country. There is a market in both countries. Then, each firm sells a part of its output on its domestic market and exports the other part to the foreign market. Here, technology diffusion occurs through the bilateral trade between the North and the South.

Another difference with respect to Miyagiwa and Ohno (1999) is that, initially, the Northern firm already benefits from the new technology while the Southern firm uses the old technology. Developed countries benefit from a larger capital endowment while developing countries benefits from a larger labor endowment. Here, technology diffusion relates to transfer from the Northern firm to the Southern firm. The new technology diffusion is endogenous. The agricultural sector is a significant example because developing countries' productivity is lower than rich countries'.

We study the case where the Northern firm files a patent to increase the monopoly period with the new technology. A patent represents a way to protect the Northern firm's information and so slow down technology diffusion. The Southern firm can use the new technology only upon the term of the patent. In this sort of North-South framework, we consider that the Northern country's patent always slows down the new technology diffusion to the Southern country. We omit the possibility of patent citations. Nevertheless, this relates to a situation where patents involve disputes between firms or countries. For example, in 2012, The New York Times published an article about 
technology war between Google and Apple by mentioning that patents are a way to prevent a firm

from being competitive in a specific market and that firms often file lawsuit because of patent infringements. ${ }^{1}$

First, we consider a simple case where a patent involves only the protection of a process. We disregard the fact that patents might encourage inventions or innovations. Second, we consider a situation where the Northern firm invests in its technological advantage by implementing costreducing R\&D investment. Furthermore, we take into account the fact that the Northern firm faces a patent filing cost. Papers that study the optimal patent length generally do not introduce this variable. Papers that introduce patent cost study the effect of the patent as compared to a situation without patent but do not study the optimal patent length. Here, we attempt to implement a new structure by applying both patent length and patent filing cost. Such cost increases with the term of patent because the Northern firm has to pay maintenance fees to keep the patent in force. Then, the Northern firm selects patent expenditures by choosing the term of patent. According to TRIPs Agreements (Article 33), "The term of protection available shall not end before the expiration of a period of twenty years counted from the filing date." Note that pharmaceutical firms have the opportunity to benefit from a supplemental protection certificate that protects innovations for further five years. Generally, when a firm files a patent, there are annual maintenance fees to be paid. This is the reason why the length of protection generally ends before the stated twenty years. Moreover, firms can publish a utility model that has fewer requirements instead of the classic patent. Utility models are one particular type of patent that are less stringent in terms of protection length and filing cost. Usually, the term of utility model is around ten years. Note that the Northern firm's patent only slows down diffusion because technology diffusion is not avoidable (Keller, 2002). Consequently, an infinite patent length is not possible.

We analyze the effect of policy instruments on technology diffusion through the impact on the Northern firm's patent expenditures: (i) a production subsidy, a patent subsidy and an import tariff implemented by the Northern government, (ii) a production subsidy, a public R\&D investment, an R\&D subsidy and an import tariff implemented by the Southern government. We focus on

\footnotetext{
${ }^{1}$ See the newspaper article of The New York Times (October 7, 2012) by Charles Duhigg and Steve Lohr entitled "In technology wars, using the patent as a sword."
} 
"behind-the-border" policies such as subsidies and "at-the-border" policies such as import tariffs.

Currently, governments use "behind-the-border" policies more frequently for three reasons: (i) they are a means to give domestic firms an advantage over foreign firms; (ii) they escape the notice of the World Trade Organization (WTO) which is more effective in prohibiting instruments representing a direct barrier against international trade flows; (iii) according to the WTO, import tariffs are bound and cannot be increased above a certain level. Evenett (2013) describes the rise in trade policy instruments as the "protectionism's quiet return" and mentions that "non-traditional forms of protections still dominate crisis-era protectionism [p. 28]." Traditional forms such as tariffs only represent less than 40 percent of the protectionism measures implemented since 2008. Production subsidy is classic trade policy. Nevertheless, agricultural tariffs are high in both developed and developing countries. In 2004, the average rates of protection were 13.9 percent for OECD members, 19.6 percent for middle income countries, and 15.3 percent for less developed countries (Source: MacMap 2008). For example, in Asia, the average tariff was 22.5 percent.

The WTO tries to prevent production subsidies because it can create trade distortions. However, governments can easily subsidize indirectly a domestic firm's production via tax cuts or employment subsidies. The Southern government's subsidy is a way to ascertain whether or not a trade policy implemented by the Southern government accelerates technology diffusion. The Northern government can also subsidize its domestic firm's patent expenditures. This is a patent subsidy. In 2002, the Belgian government implemented subsidies for small and medium-sized businesses "to register and to maintain a patent." In 2010, the subsidy rate achieved 70 percent of the patent filing cost (Source: Europa). Munari and Xu (2011) conduct an overview of ten experiences of patent subsidies throughout the 2000s: "the use of patent subsidies, in particular in favor of SMEs, has recently gained an increased attention by policy-makers [p. 5]."

The results of this paper show that policy instruments implemented by the Northern country slow down technology diffusion between the two firms by increasing the monopoly period with the new technology. But the patent subsidy decreases the Northern country's national welfare. In this case, the Northern government is encouraged to tax its domestic firm's patent expenditures. The production subsidy and the tariff always increase the Northern country's national welfare up to an optimal level. Furthermore, the Southern government's policy instruments accelerate technology 
diffusion by reducing the monopoly period with the new technology and increase the domestic national welfare.

Finally, we consider a further assumption whereby the Northern firm invests in its technological advantage corresponding to the patent length by implementing cost-reducing R\&D investment. In this case, R\&D investment increases profit flows. Here, it corresponds to what economic literature calls patent breadth. The objective of such an assumption is to verify whether or not the patent subsidy involves a positive impact on the Northern country's national welfare in order to understand the growing interest shown by policy makers in this type of subsidy. The results show that the Northern government may be encouraged to implement a patent subsidy while a patent tax is always optimal without investments in technological advantage. Through this, we understand that patents increase national welfare only if patentee firms invest in their technological advantages.

Section 2 introduces the model. Section 3 analyzes the impact of the Northern government's "behind-the-border" policy instruments on the speed of the new technology diffusion. Section 4 analyzes the impact of the Southern government's "behind-the-border" policy instruments. Section 5 analyzes the impact of import tariffs. Section 6 presents the welfare analysis where we verify whether or not governments are encouraged to implement each policy instrument. Section 7 introduces the assumption whereby the Northern firm invests in its technological advantage. Section 8 introduces Bertrand competition. Section 9 concludes.

\section{The Model}

Consider a duopoly with a firm from a Northern country and another from a Southern country. There is competition on two differentiated markets. Each firm sells a part of its output domestically and exports the other part to the foreign market. Therefore, we introduce bilateral trade in the model. Let us suppose a dynamic model where time is continuous and defined over $[0, \infty)$. Initially, the Northern firm benefits from a new technology denoted by $\bar{\mu}$ while the Southern firm only uses an old technology denoted by $\underline{\mu}^{*}$. Here, technology diffusion is defined by technology transfer from the Northern firm to the Southern firm. The new technology diffusion occurs at period $T$ over $[0, \infty)$. The Southern firm can use the new technology $\bar{\mu}^{*}$ from such a point in time. The Northern firm benefits from $\bar{\mu}$ over $[0, \infty)$. Here, we consider that the new technology diffusion 
occurs due to information diffusion via telecommunications such as the Internet and due to the bilateral trade between the North and the South.

Assumption 1: The Northern (respectively Southern) firm's marginal cost is constant and denoted by $c$ (respectively $c^{*}$ ). Each firm's technological endowment influences its marginal cost: $c=c(\mu)$, with $\mu=\bar{\mu}, c^{*}=c^{*}\left(\mu^{*}\right)$, with $\mu^{*}=\underline{\mu}^{*}, \bar{\mu}^{*}$. We have: $c^{*}\left(\underline{\mu^{*}}\right)>c^{*}\left(\bar{\mu}^{*}\right)$.The value of $c^{*}$ changes at time $T$.

Note that such a structure relates to an empirical example, for instance the agricultural sector. The assumption of the existence of two markets works because there are high levels of agricultural bilateral trade between Northern and Southern countries. Northern and Southern producers also differ in productivity. Developing countries' agricultural productivity is lower than developed countries' (Fulginiti and Perrin, 1999). The role of technological endowment is crucial. For example, O'Neill (2000) mentions that "the application of ergonomics differs between IDCs [Industrially Developing Countries] and IACs [Industrially Advanced Countries] particularly through the limited infrastructure in IDCs to support ergonomics activity and interventions [p. 631]." Another interesting feature of the agricultural sector is that producers from rich countries files patents to protect their technologies. For example, developed countries' intellectual property leads to a difficult access to modern agricultural biotechnologies for developing countries (Adenle et al., 2012). Furthermore, firms files patents on both products and processes: nanotechnologies, biotechnologies, plants (Alendete-Saez et al., 2014). In this paper, we consider a process patent on a new technology.

Consider a two-stage model. At each point in time, both firms select the level of output that maximizes its static profit flows. The Northern firm files a patent to increase the monopoly period with the new technology. The patent filing cost increases with the patent length. Then, the Northern firm selects its patent-related expenditures (i.e. the patent length) that maximize its discounted sum of profit flows.

\subsection{The Static Structure}

The Northern (Southern) firm produce the total quantity of output $x+x^{*}\left(y+y^{*}\right)$ where $x$ $\left(y^{*}\right)$ denotes the sales on its domestic market and $x^{*}(y)$ its exports to the foreign market at each point in time over $[0, \infty)$. Both firms sell a homogenous good on each market. 
Assumption 2: At each point in time, there is Cournot competition on both markets. ${ }^{2}$ Each

firm sells a homogenous good. We denote $p\left(p^{*}\right)$ the Northern (Southern) market price with the inverse demand functions: $p(X)=p(x+y), p^{*}\left(X^{*}\right)=p\left(x^{*}+y^{*}\right)$, where $X\left(X^{*}\right)$ denotes the total supply on the Northern (Southern) market. The market prices decrease with the total supplies: $p^{\prime}=\mathrm{d} p / \mathrm{d} X<0, p^{* \prime}=\mathrm{d} p^{*} / \mathrm{d} X^{*}<0$.

At each point in time, the static profit flows are:

$$
\begin{aligned}
& \pi\left(x, x^{*}, y, y^{*}\right)=x p(x+y)+x^{*} p^{*}\left(x^{*}+y^{*}\right)-c(\bar{\mu})\left(x+x^{*}\right)-g x^{*} \\
& \pi^{*}\left(x, x^{*}, y, y^{*}\right)=y p(x+y)+y^{*} p^{*}\left(x^{*}+y^{*}\right)-c^{*}\left(\mu^{*}\right)\left(y+y^{*}\right)-g^{*} y, \text { with } \mu^{*}=\underline{\mu}^{*}, \bar{\mu}^{*}
\end{aligned}
$$

Consider linear transport costs denoted by $g x^{*}$ and $g y$ where the terms $g$ and $g^{*}$ are constant unit transport costs. The unit transport cost does not depend on the technological endowment because geographic distance is the most significant factor of transport cost. Note that we omit the existence of a fixed cost because it does not really influence the results of the model.

Each firm selects the levels of domestic sales and exports that maximize its profit. The First Order Conditions give the following reaction functions on the Northern market:

$$
x(y)=[c(\bar{\mu})-p(x+y)] / p^{\prime}, y(x)=\left[c^{*}\left(\mu^{*}\right)+g^{*}-p(x+y)\right] / p^{\prime}, \text { with } \mu^{*}=\underline{\mu}^{*}, \bar{\mu}^{*}
$$

Reactions functions on the Southern market are symmetric. Each profit decreases with the foreign domestic sales and exports: $\pi_{y}=x p^{\prime}<0, \pi_{y^{*}}=x^{*} p^{* \prime}<0, \pi_{x}^{*}=y p^{\prime}<0, \pi_{x^{*}}^{*}=y^{*} p^{* \prime}<$ $0 .^{3}$

Assumption 3: The second order conditions are verified: $\pi_{x x}<0, \pi_{x^{*} x^{*}}<0, \pi_{y y}^{*}<0$, $\pi_{y^{*} y^{*}}^{*}<0$. Cross effects are also negative: $\pi_{x y}<0, \pi_{x^{*} y^{*}}<0, \pi_{y x}^{*}<0, \pi_{y^{*} x^{*}}^{*}<0$. Own effects are stronger than cross effects: $\left|\pi_{x x}\right|>\left|\pi_{x y}\right|,\left|\pi_{x^{*} x^{*}}\right|>\left|\pi_{x^{*} y^{*}}\right|,\left|\pi_{y y}^{*}\right|>\left|\pi_{y x}^{*}\right|,\left|\pi_{y^{*} y^{*}}^{*}\right|>\left|\pi_{y^{*} x^{*}}^{*}\right|$. Stability conditions are verified: $D=\pi_{x x} \pi_{y y}^{*}-\pi_{x y} \pi_{y x}^{*}>0, D^{*}=\pi_{x^{*} x^{*}} \pi_{y^{*} y^{*}}^{*}-\pi_{x^{*} y^{*}} \pi_{y^{*} x^{*}}^{*}>0$.

In this model, technology diffusion influences the level of the Southern firm's marginal cost $c^{*}$. We search the effect of $c^{*}$ on domestic sales, exports, prices and profits to determine the effect of the Southern firm's technological endowment. On the Northern market, differentiating the first order conditions with respect to $x, y$ and $c^{*}$, we have: $\mathrm{d} x / \mathrm{d} c^{*}=-\pi_{x y} / D>0, \mathrm{~d} y / \mathrm{d} c^{*}=\pi_{x x} / D<$

\footnotetext{
${ }^{2}$ Note that the assumption of Cournot competition works with the agricultural sector because prices depend on the quantities of supply and demand on financial markets.

${ }^{3}$ We use subscripts to denote partial derivatives.
} 
$0, \mathrm{~d} X / \mathrm{d} c^{*}=\left(\pi_{x x}-\pi_{x y}\right) / D<0$. The Southern firm's marginal cost reduces (increases) the Southern (Northern) firm's exports (domestic sales). It reduces the total supply on the Northern market. It increases the market price: $\mathrm{d} p / \mathrm{d} c^{*}=p^{\prime} \mathrm{d} X / \mathrm{d} c^{*}>0$. Therefore, it reduces the Northern country's consumer surplus by increasing $p$ and reducing $X$. The results are the same for the Southern market and the expressions are symmetric.

Let us search the effect on profits by using the maximum profits. We denote $\hat{\pi}$ and $\hat{\pi}^{*}$ the profits such as:

$$
\begin{aligned}
& \hat{\pi}\left(c^{*}\right)=\max _{x, x^{*}>0} \pi\left(x, x^{*}, y, y^{*}\right) \text { subject to } \pi_{y}^{*}=0 \text {, i.e. } \hat{\pi}\left(c^{*}\right)=\pi\left[\hat{x}\left(c^{*}\right), \hat{x}^{*}\left(c^{*}\right)\right] \\
& \hat{\pi}^{*}\left(c^{*}\right)=\max _{y, y^{*}>0} \pi^{*}\left(x, x^{*}, y, y^{*}\right) \text { subject to } \pi_{x}=0 \text {, i.e. } \hat{\pi}^{*}\left(c^{*}\right)=\pi^{*}\left[\hat{y}\left(c^{*}\right), \hat{y}^{*}\left(c^{*}\right)\right](5)
\end{aligned}
$$

$\hat{x}$ and $\hat{x}^{*}\left(\hat{y}\right.$ and $\left.\hat{y}^{*}\right)$ denotes the Northern (Southern) firm's domestic sales and exports that makes possible to achieve the maximum profit. The First Order Conditions involve: $\pi\left[\hat{x}\left(c^{*}\right), \hat{x}^{*}\left(c^{*}\right)\right]=-\hat{x}\left(c^{*}\right)^{2} p^{\prime}-\hat{x}^{*}\left(c^{*}\right)^{2} p^{* \prime}, \pi^{*}\left[\hat{y}\left(c^{*}\right), \hat{y}^{*}\left(c^{*}\right)\right]=-\hat{y}\left(c^{*}\right)^{2} p^{\prime}-\hat{y}^{*}\left(c^{*}\right)^{2} p^{* \prime}$. We have:

$$
\begin{aligned}
& \frac{\mathrm{d} \hat{\pi}\left(c^{*}\right)}{\mathrm{d} c^{*}}=\frac{\hat{x} \pi_{x x} \pi_{x y}}{D}+\frac{\hat{x}^{*} \pi_{x^{*} x^{*}} \pi_{x^{*} y^{*}}}{D^{*}}>0 \\
& \frac{\mathrm{d} \hat{\pi}^{*}\left(c^{*}\right)}{\mathrm{d} c^{*}}=-\left(\frac{\hat{y} \pi_{x x} \pi_{y y}^{*}}{D}+\frac{\hat{y}^{*} \pi_{x^{*} x^{*} \pi_{y^{*} y^{*}}^{*}}}{D^{*}}\right)<0
\end{aligned}
$$

Therefore, the Southern firm's marginal cost reduces (increases) the Southern (Northern) firm's profit. The Southern firm is clearly encouraged to benefit from the new technology diffusion.

According to previous results, outputs, price and profits depend on the Southern firm's technological endowment. Domestic sales, exports and profit flows of the Northern (Southern) firm are higher (lower) when the Southern firm uses the old technology: $x\left(\underline{\mu}^{*}\right)>x\left(\bar{\mu}^{*}\right), x^{*}\left(\underline{\mu}^{*}\right)>$ $x^{*}\left(\bar{\mu}^{*}\right), y\left(\underline{\mu}^{*}\right)<y\left(\bar{\mu}^{*}\right), y^{*}\left(\underline{\mu}^{*}\right)<y^{*}\left(\bar{\mu}^{*}\right), \pi\left(\underline{\mu}^{*}\right)>\pi\left(\bar{\mu}^{*}\right), \pi^{*}\left(\underline{\mu}^{*}\right)<\pi^{*}\left(\bar{\mu}^{*}\right)$. Total supplies are lower and market prices are stronger: $X\left(\underline{\mu}^{*}\right)<X\left(\bar{\mu}^{*}\right), X^{*}\left(\underline{\mu}^{*}\right)<X^{*}\left(\bar{\mu}^{*}\right), p\left(\underline{\mu}^{*}\right)>p\left(\bar{\mu}^{*}\right)$, $p^{*}\left(\underline{\mu}^{*}\right)>p^{*}\left(\bar{\mu}^{*}\right)$. Then, each country's consumer surplus is lower. 


\subsection{A Linear Example}

In the body of this paper, we use specific inverse demand functions to have a clear outcome. Consider linear inverse demand functions: $p(X)=a-X, p\left(X^{*}\right)=a^{*}-X^{*}$. Each firm selects the optimal levels of domestic sales and exports:

$$
\hat{x}=\frac{a-2 c+c^{*}+g^{*}}{3}, \hat{x}^{*}=\frac{a^{*}-2 c+c^{*}-2 g}{3}, \hat{y}=\frac{a+c-2 c^{*}-2 g^{*}}{3}, \hat{y}^{*}=\frac{a^{*}+c-2 c^{*}+g}{3}
$$

We can easily demonstrate that the Southern firm's marginal cost increases (reduces) the Northern (Southern) firm's domestic sales and exports.

The equilibrium levels of price are:

$$
\hat{p}=\frac{a+c+c^{*}+g^{*}}{3}, \hat{p}^{*}=\frac{a^{*}+c+c^{*}+g}{3}
$$

Each market price increases with the Southern firm's marginal cost.

Finally, the equilibrium profits are:

$$
\hat{\pi}=\frac{\left(a-2 c+c^{*}+g^{*}\right)^{2}+\left(a^{*}-2 c+c^{*}-2 g\right)^{2}}{9}, \hat{\pi}^{*}=\frac{\left(a+c-2 c^{*}-2 g^{*}\right)^{2}+\left(a^{*}+c-2 c^{*}+g\right)^{2}}{9}
$$

The Northern (Southern) firm's profit increases (decreases) with the Southern firm's marginal cost.

\subsection{The Dynamic Structure}

The Northern firm enjoys a monopoly with the new technology until $T$ and files a patent at time 0 in the Southern country's office in order to increase the said monopoly. The period $[0, T)$ is called the monopoly period. The patent filing engenders a filing cost which increases with the said patent length. The variable $k$ denotes the Northern firm's expenditures needed to implement the patent.

Assumption 4: The Northern firm's monopoly period $T$ with the new technology depends on the patent expenditures $k: T=T(k) . T$ increases with $k: T^{\prime}(k)=\mathrm{d} T(k) / \mathrm{d} k>0 . T$ increases with $k: T^{\prime}(k)=\mathrm{d} T(k) / \mathrm{d} k>0$. Furthermore, we have: $T^{\prime \prime}(k)=\mathrm{d}^{2} T(k) / \mathrm{d} k^{2} \leq 0$.

Note that it seems intuitive to consider a linear relationship between the monopoly period $T$ and the patent expenditures $k$ i.e. $T^{\prime \prime}=0$. Nevertheless, we may also consider $T^{\prime \prime}<0$ because the Southern firm may benefit from diffusion of an alternative modern technology that is not patented over time. On the other hand, it seems complex to consider $T^{\prime \prime}>0$. Hence, we have: $T^{\prime \prime} \leq 0$. In the 
body of the paper, we use a general form for the function $T$. But we will use a specific linear function for the welfare analysis.

Assumption 5: The Northern firm is encouraged to file the patent: $\pi\left(\underline{\mu}^{*}\right)-k>\pi\left(\bar{\mu}^{*}\right)$.

The Northern firm selects the optimal level of patent expenditures $k$ by choosing the optimal level of patent length. It maximizes a discounted sum of profit flows, denoted by $\Pi$, with respect to $k$ by anticipating the previous static results:

$$
\max _{k \geq 0} \Pi(k)=\int_{0}^{T(k)} e^{-i \tau} \hat{\pi}\left(\underline{\mu}^{*}\right) \mathrm{d} \tau+\int_{T(k)}^{\infty} e^{-i \tau} \hat{\pi}\left(\bar{\mu}^{*}\right) \mathrm{d} \tau-k
$$

where $i$ denotes the interest rate that discounts flows. Time is denoted as $\tau$. We use exponentials because of continuous time. Integrating, we have:

$$
\max _{k \geq 0} \Pi(k)=\frac{\left[1-e^{-i T(k)}\right] \widehat{\pi}\left(\underline{\mu}^{*}\right)+e^{-i T(k)} \hat{\pi}\left(\bar{\mu}^{*}\right)}{i}-k
$$

The first order condition $\Pi_{k}=0$ involves:

$$
\frac{1}{T^{\prime}(k) e^{-i T(k)}}=\hat{\pi}\left(\underline{\mu}^{*}\right)-\hat{\pi}\left(\bar{\mu}^{*}\right)
$$

The second order condition is verified: $\Pi_{k k}=\left[T^{\prime \prime}(k)-i T^{\prime}(k)^{2}\right] e^{-i T(k)}\left[\hat{\pi}\left(\underline{\mu}^{*}\right)-\hat{\pi}\left(\bar{\mu}^{*}\right)\right]<$ 0 . We denote as $K(k)$ the left side of the previous equation. We have: $K(k)=\hat{\pi}\left(\underline{\mu}^{*}\right)-\hat{\pi}\left(\bar{\mu}^{*}\right)$. The function $K$ increases with $k$ :

$$
K^{\prime}(k)=\frac{i T^{\prime}(k)^{2}-T^{\prime \prime}(k)}{T^{\prime}(k)^{2} e^{-i T(k)}}>0
$$

A simple interpretation of (14) stems from rewriting as: $k=\psi\left[\hat{\pi}\left(\underline{\mu^{*}}\right)-\hat{\pi}\left(\bar{\mu}^{*}\right)\right]$ with $\partial \psi / \partial\left[\hat{\pi}\left(\underline{\mu}^{*}\right)-\hat{\pi}\left(\bar{\mu}^{*}\right)\right]>0$. Hence, $k$ increases with the difference in profit $\left[\hat{\pi}\left(\underline{\mu}^{*}\right)-\hat{\pi}\left(\bar{\mu}^{*}\right)\right]$.

\section{The Impact of "Behind-The-Border" Policies Implemented by The Northern Government}

Let us study the impact of "behind-the-border" policy instruments implemented by the Northern government. We analyze the impact of two subsidies: a production subsidy and a patent subsidy.

Assumption 6: The production subsidy is implemented over $[0, \infty)$. But the Northern government's patent subsidy is only implemented at time 0 . 
reasons. The Northern government tries to implement an instrument that increases the Northern country's national welfare as compared to free trade. An instrument that increases the consumer surplus is politically desirable. Furthermore, it can also be justified for employment reasons in the Northern country. A subsidy from the Northern government represents a way to hire further employees in the Northern country. We make a welfare analysis in Section 6 to ascertain whether or not governments are encouraged to implement such subsidies. Note that we implement the following structure. See Figure 1.

Figure 1 - Structure of The Model

\begin{tabular}{|c|c|c|c|c|c|}
\hline 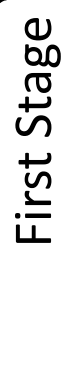 & $\begin{array}{l}\text { The government } \\
\text { selects the optimal } \\
\text { level of the policy } \\
\text { instrument at period } 0 \\
\text { by anticipating the } \\
\text { results of each firm. }\end{array}$ & 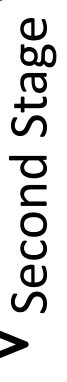 & $\begin{array}{l}\text { The Northern firm } \\
\text { selects the optimal } \\
\text { level of patent } \\
\text { expenditures at period } \\
0 \text { by anticipating each } \\
\text { equilibrium levels of } \\
\text { domestic sales and } \\
\text { exports at each point in } \\
\text { time. }\end{array}$ & 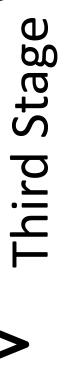 & $\begin{array}{l}\text { Each firm selects the } \\
\text { optimal level of } \\
\text { domestic sales and } \\
\text { exports at each point in } \\
\text { time. }\end{array}$ \\
\hline
\end{tabular}

Source: author.

First, the government selects the optimal value of its subsidy. For example, when the Northern government wants to subsidize its domestic firm's production, it implements the optimal level of production subsidy. If the said level is positive, the production subsidy is optimal. But if it is negative, a production tax is optimal. The government anticipates the equilibrium levels of domestic sales, exports, prices and profits flows of each firm and the Northern firm's patent expenditures. Hence, the Northern government maximizes the Northern country's national welfare W which is given by: $\mathrm{W}=\Pi+\mathrm{CS}+\mathrm{PR}$, where $\mathrm{CS}$ denotes the Northern country's discounted consumer surplus and PR denotes the Northern government's discounted public revenues i.e. the governmental surplus. At each point in time, the Northern country's static consumer surplus is given by: $\int_{0}^{\hat{X}\left(\mu^{*}\right)} p\left[X\left(\mu^{*}\right)\right] \mathrm{d} X\left(\mu^{*}\right)-\hat{X}\left(\mu^{*}\right) p\left[\hat{X}\left(\mu^{*}\right)\right]$, with $\mu^{*}=\underline{\mu}^{*}, \bar{\mu}^{*}$. The governmental surplus is negative when the optimal subsidy is positive. It is positive when the government implements a tax. For example, when the Northern government wants to implement a production subsidy $s$, at each point in time, the static governmental surplus equals to: $-s\left[\hat{x}\left(\mu^{*}, s\right)+\hat{x}^{*}\left(\mu^{*}, s\right)\right]$, with $\mu^{*}=\underline{\mu}^{*}, \bar{\mu}^{*}$, where $\hat{x}\left(\hat{x}^{*}\right)$ denotes the equilibrium level of the Northern firm's domestic sales (exports). 
Second, the Northern firm selects the optimal level of patent expenditures $k$ at period 0 by anticipating each static equilibrium level of domestic sales, exports and profit flows. Third, each firm selects the optimal level of domestic sales and exports at each point in time. Note that we solve the model by starting with the third stage for each instrument. We find the optimal level of patent expenditures $k$, then. We finish by finding the optimal level of the public policy instrument because we need to know the equilibrium expression for each variable.

\subsection{The Northern Government's Production Subsidy}

The Northern government subsidizes its domestic firm's production. We denote as $s$ the specific production subsidy. The Southern firm's profit expression remains the same as in Equation (2). The Northern firm's profit expression becomes:

$$
\pi=x p(x+y)+x^{*} p^{*}\left(x^{*}+y^{*}\right)-[c(\bar{\mu})-s]\left(x+x^{*}\right)-g x^{*}
$$

Let us now find the effect of the subsidy on domestic sales, exports, prices and profits. This is easily determined because we have already studied the impact of the Southern firm's marginal cost. According to Equation (15), the production subsidy $s$ has the same impact on profit as a negative marginal cost. Then, the subsidy $s$ increases (reduces) the Northern (Southern) firm's domestic sales and exports, increases total supplies, and lowers market prices on both markets by reducing the Northern firm's total cost. Therefore, it increases consumer surplus. Finally, it increases (reduces) the Northern (Southern) firm's profit. We have:

$$
\frac{\mathrm{d} \widehat{\pi}\left(\mu^{*}, s\right)}{\mathrm{d} s}=\frac{4\left[a+a^{*}-4 c(\bar{\mu})+2 c^{*}\left(\mu^{*}\right)-4 g+2 g^{*}+4 s\right]}{9}=\frac{4\left[\hat{x}\left(\mu^{*}, s\right)+\hat{x}^{*}\left(\mu^{*}, s\right)\right]}{3}>0, \text { with } \mu^{*}=\underline{\mu}^{*}, \bar{\mu}^{*}
$$

Now, we look for the effect of the subsidy $s$ on the speed of the new technology diffusion. We search for the effect on $k$. The Northern firm selects the patent expenditures (i.e. the patent length) that maximize its discounted sum of profit flows. The first order condition involves the same expression as under free trade except that the profit flows now depend on the production subsidy $s$.

Proposition 1: The Northern government's production subsidy increases the Northern firm's patent expenditures $k$ and the monopoly period $T$. Therefore, it slows down the new technology diffusion from the North to the South.

Proof: The Northern firm's patent expenditures $k$ depend on the difference in profit $\left[\hat{\pi}\left(\underline{\mu}^{*}, s\right)-\hat{\pi}\left(\bar{\mu}^{*}, s\right)\right]$. An increase in the said difference involves an increase in $k$. The production 
subsidy raises $k$ if the gain in Northern firm's profit flows is stronger when the Southern firm uses the

old technology i.e. $\hat{\pi}_{s}\left(\underline{\mu}^{*}, s\right)>\hat{\pi}_{s}\left(\bar{\mu}^{*}, s\right)$.

According to Equation (16), the positive effect of the subsidy $s$ on the Northern firm's profit flows increases with the Southern firm's marginal cost. Such a results means that the difference in profit increases with the production subsidy. Then, the Northern firm's patent expenditures as compared to free trade: $\mathrm{d} k / \mathrm{d} s>0$. The Northern government's production subsidy slows down the new technology diffusion by increasing the monopoly period $T$.

The Northern government's production subsidy increases $k$ because the positive effect on its profit is stronger when the Southern firm uses the old technology (its output is greater). The Northern firm is encouraged to increase the patent expenditures in order to benefit from a longer monopoly period with the new technology. The subsidy $s$ slows down the new technology diffusion. The production subsidy leads to further revenues for the Northern firm. Such revenues increase with the level of output $\left(x+x^{*}\right)$. The Northern firm is encouraged to increase expenditures $k$ to benefit from stronger market shares and from higher revenues. Note that the sign of the impact would be the same if the Northern government only subsidizes domestic sales or exports because the expressions are symmetric.

Nevertheless, the form of inverse demand functions may influence the results. We cannot demonstrate that the production subsidy increases patent expenditures by using general forms. See Appendix A. Using any other linear form, the impact is always positive. But under nonlinear forms, the results may differ owing to second order effects.

\subsection{The Northern Government's Patent Subsidy}

The Northern government can subsidize its domestic firm's patent expenditures instead of production. The said patent subsidy is denoted as $\varphi$. The static profit flows expressions are the same as under free trade. Unlike a production subsidy, it does not directly affect outputs, price and profit flows. But it does reduce the patent filing cost. The real cost now equals to: $(1-\varphi) k$. The Northern firm's discounted sum of profit flows is:

$$
\max _{k \geq 0} \Pi(k, \varphi)=\int_{0}^{T(k)} e^{-i \tau} \hat{\pi}\left(\underline{\mu}^{*}\right) \mathrm{d} \tau+\int_{T(k)}^{\infty} e^{-i \tau} \hat{\pi}\left(\bar{\mu}^{*}\right) \mathrm{d} \tau-(1-\varphi) k
$$


The Northern firm selects $k$ which maximizes its discounted sum of profit flows. The first order condition involves:

$$
K(k)=\frac{\widehat{\pi}\left(\underline{\mu}^{*}\right)-\widehat{\pi}\left(\bar{\mu}^{*}\right)}{1-\varphi}
$$

Proposition 2: The Northern government's patent subsidy always increases the Northern firm's patent expenditures $k$ and the monopoly period $T$. It slows down the new technology diffusion.

Proof: Thanks to Equation $(18), k$ decreases with $(1-\varphi)$ i.e. it increases with $\varphi$. The difference in profit does not depend on $\varphi$. Therefore, the subsidy increases the Northern firm's patent expenditures and the monopoly period: $\mathrm{d} k / \mathrm{d} \varphi>0, \mathrm{~d} T / \mathrm{d} \varphi>0$. It slows down the new technology diffusion.

Such a subsidy reduces the Northern firm's total patent filing cost. The firm benefits from further revenues that increase with its expenditures. It explains why the firm is encouraged to increase $k$. The monopoly period with the new technology increases when the total patent filing cost does not vary. In this sense, a patent subsidy is more efficient than a production subsidy to encourage a firm to protect its technological advantage.

\section{The Impact of "Behind-The-Border" Policies Implemented by The Southern Government}

The Southern government can implement policy instruments in order to accelerate technology diffusion. Consider that the Northern government remains under free trade. The structure is the same as in Figure 1.

\subsection{The Southern Government's Production Subsidy}

The Southern government implements a specific production subsidy at each point in time. We denote as $s^{*}$ the Southern government's subsidy. The Southern firm's profit expression becomes:

$$
\pi^{*}=y p(x+y)+y^{*} p^{*}\left(x^{*}+y^{*}\right)-\left[c\left(\mu^{*}\right)-s^{*}\right]\left(y+y^{*}\right)-g^{*} y, \text { with } \mu^{*}=\underline{\mu}^{*}, \bar{\mu}^{*}
$$

The effects of the subsidy $s^{*}$ on production sales, exports, prices and profits are symmetrical to those of the subsidy s. The Southern government's subsidy increases (reduces) the Southern (Northern) firm's domestic sales, exports and profit. It also increases each country's consumer 
surplus by increasing the total supply and lowering the market price. Note that the effect of $s^{*}$ on the Northern firm's profit is given by:

$$
\frac{\mathrm{d} \widehat{\pi}\left(\mu^{*}, s^{*}\right)}{\mathrm{d} s^{*}}=-\frac{2\left[a+a^{*}-4 c(\bar{\mu})+2 c^{*}\left(\mu^{*}\right)-4 g+2 g^{*}-2 s^{*}\right]}{9}=-\frac{2\left[\hat{x}\left(\mu^{*}, s^{*}\right)+\hat{x}^{*}\left(\mu^{*}, s^{*}\right)\right]}{3}<0, \quad \text { with } \mu^{*}=\underline{\mu}^{*}, \bar{\mu}^{*}
$$

The Northern firm selects $k$ that maximizes its discounted sum of profit flows. The first order condition gives the same expression as under free trade except that the profit flows now depend on the subsidy $s^{*}$.

Proposition 3: The Southern government's production subsidy accelerates technology diffusion by decreasing $k$ and $T$ as compared to free trade.

Proof: We have to find the effect of the subsidy $s^{*}$ on the difference in profit $\left[\hat{\pi}\left(\underline{\mu}^{*}, s^{*}\right)-\right.$ $\left.\hat{\pi}\left(\bar{\mu}^{*}, s^{*}\right)\right]$. According to Equation (20), the negative effect of $s^{*}$ on $\pi$ is stronger when $c^{*}$ increases. The negative effect is stronger before the new technology diffusion. The difference in profit decreases as compared to free trade. Then, the Northern firm is encouraged to reduce its patent expenditures $k: \mathrm{d} k / \mathrm{d} s^{*}<0$. The Southern government's production subsidy accelerates technology diffusion by reducing the monopoly period $T$.

The Southern government's production subsidy increases the Southern firm's output. Its domestic sales and exports increase as compared to free trade. Using the specific linear demand functions, we can find the direct impact of the Southern firm's domestics sales and exports on the Northern firm's profit: $\pi_{y}=-x<0, \pi_{y^{*}}=-x^{*}<0$. Hence, the negative impact of the increase in $y$ and $y^{*}$ on $\pi$ increases with $x$ and $x^{*}$. The total output $\left(x+x^{*}\right)$ is higher before the new technology diffusion. Then, the Northern firm is encouraged to reduce its patent expenditures.

Nevertheless, the form of inverse demand functions may influence the results again. We cannot demonstrate that the production subsidy increases patent expenditures by using general forms. See Appendix A.

\subsection{The Southern Government's Public R\&D Investment/R\&D Subsidy}

Under the initial case, the Southern firm does not invest in R\&D because the cost of such an investment is too high. Southern economies' R\&D expenditures are lower than Northern economies' 
because skilled labor and modern telecommunications are scarce and costly. The Southern

government can also encourage innovations in its domestic country. Consider a cost-reducing R\&D investment denoted as $r^{*}$ and implemented at period 0 . We denote as $v^{*}$ the unit cost of R\&D. There are two cases:

- The Southern government directly invests in R\&D by implementing a public R\&D program. The Southern firm benefits from another technological endowment owing to such public innovations. In this case, the Southern government selects the optimal level of public R\&D that maximizes the Southern country's national welfare by anticipating the Northern firm's patent expenditures.

- The Southern government subsidizes the Southern firm to promote a private R\&D program by reducing the total cost of $R \& D$ expenditures. We denote as $\sigma^{*}$ the $R \& D$ subsidy. The Southern firm selects the optimal level of R\&D that maximizes its discounted sum of profit flows.

Nevertheless, the Southern firm only benefits from an intermediate technology over $[0, T)$ with such an R\&D investment. The dynamic structure would be unnecessary, otherwise, because the Southern firm would benefit from the new technology at period 0 . It would be less credible because the speed of technology diffusion often depends on rich countries' behaviors. Furthermore, Southern countries' innovations are too low. ${ }^{4}$ These countries generally benefit from foreign sources of productivity (Keller, 2004).

Assumption 7: The Southern country implements an R\&D investment denoted by $r^{*}$ at period 0 that reduces the marginal $\operatorname{cost} c^{*}$ over $[0, T)$. The Southern firm can use an intermediate technology over $[0, T)$. The returns are decreasing: $\mathrm{d} c^{*} / \mathrm{d} r^{*}<0, \mathrm{~d}^{2} c^{*} / \mathrm{d} r^{* 2} \geq 0$ (Brander and Spencer, 1983). Then, the function of marginal cost is concave.

We denote as $\mu_{r^{*}}^{*}$ the intermediate technology that depends on the level of R\&D investments $r^{*}$ such as: $c^{*}\left(\underline{\mu^{*}}\right)>c^{*}\left[\mu_{r^{*}}^{*}\left(r^{*}\right)\right]>c^{*}\left(\bar{\mu}^{*}\right)$. When the new technology diffusion occurs, the R\&D investment no longer influences the Southern firm's marginal cost. The static profit expression of the Southern firm is the same as in Equation (2). But we have $\mu^{*}=\mu_{r^{*}}^{*}\left(r^{*}\right)$ over $[0, T)$. According to the impact of $c^{*}$ on each variable, we can easily find the impact of $r^{*}$. The R\&D investment increases (reduces) the Southern (Northern) firm's domestic sales, exports and profit

\footnotetext{
${ }^{4}$ Developing countries' R\&D expenditures often represent less than one percent of their Gross Domestic Product (Source: World Bank WDI).
} 
flows. It also reduces the market prices. The effect on the total supply on each market is positive.

Then, each country's consumer surplus increases with the R\&D.

The Northern firm's discounted sum of profit flows is:

$$
\max _{k \geq 0} \Pi\left(k, r^{*}, \sigma^{*}\right)=\int_{0}^{T(k)} e^{-i \tau} \hat{\pi}\left[\mu_{r^{*}}^{*}\left(r^{*}\right)\right] \mathrm{d} \tau+\int_{T(k)}^{\infty} e^{-i \tau} \hat{\pi}\left(\bar{\mu}^{*}\right) \mathrm{d} \tau-k
$$

Under the first case, the Southern firm's discounted sum of profit flows increases with the public R\&D investment. But the Southern firm does not maximize such discounted sum: the Southern government selects the level of R\&D that maximizes the Southern country's national welfare.

Under the second case, the Southern firm's selects the optimal level of R\&D investment:

$$
\max _{r^{*} \geq 0} \Pi^{*}\left(k, r^{*}, \sigma^{*}\right)=\int_{0}^{T(k)} e^{-i \tau} \hat{\pi}^{*}\left[\mu_{r^{*}}^{*}\left(r^{*}\right)\right] \mathrm{d} \tau+\int_{T(k)}^{\infty} e^{-i \tau} \hat{\pi}^{*}\left(\bar{\mu}^{*}\right) \mathrm{d} \tau-\left(v^{*}-\sigma^{*}\right) r^{*}
$$

The first order conditions involve:

$$
\begin{aligned}
& \frac{1}{T^{\prime}(k) e^{-i T(k)}}=\hat{\pi}\left[\mu_{r^{*}}^{*}\left(r^{*}\right)\right]-\hat{\pi}\left(\bar{\mu}^{*}\right) \\
& \frac{\left[1-e^{-i T(k)}\right]}{i} \frac{\mathrm{d} \hat{\pi}^{*}\left[\mu_{r^{*}}^{*}\left(r^{*}\right)\right]}{\mathrm{d} r^{*}}=v^{*}-\sigma^{*}
\end{aligned}
$$

According to Assumption 7, the second order condition is verified for the Southern firm: $\Pi_{r^{*} r^{*}}^{*}<0$. We have also negative cross effects: $\Pi_{k r^{*}}<0, \Pi_{r^{*} k}^{*}<0$.

Proposition 4: The Southern government's public R\&D investment/R\&D subsidy accelerates the new technology diffusion by reducing the Northern firm's patent expenditures $k$ and the monopoly period $T$.

\section{Proof:}

- First, let us study the case of a public R\&D investment. Differentiating the Northern firm's first order condition $\Pi_{k}=0$, we have:

- $\frac{\mathrm{d} k}{\mathrm{~d} r^{*}}=-\frac{\Pi_{k r^{*}}}{\Pi_{k k}}<0$, with $\Pi_{k r^{*}}=T^{\prime}(k) e^{-i T(k)} \frac{2\left\{\hat{x}\left[\mu_{r^{*}}^{*}\left(r^{*}\right)\right]+\hat{x}^{*}\left[\mu_{r^{*}}^{*}\left(r^{*}\right)\right]\right\}}{3} \frac{\mathrm{d} c^{*}\left[\mu_{r^{*}}^{*}\left(r^{*}\right)\right]}{\mathrm{d} r^{*}}<0$

- The Northern firm's patent expenditures decrease with the public R\&D investment. The two variables are strategic substitutes. The Northern firm is encouraged to reduce its patent expenditures. The reason is that the monopoly period involves a lower gain for the Northern firm because the Southern firm uses an intermediate technology. 
- Now let us study the case of an R\&D subsidy. Differentiation the same first order conditions, we have:

- $\frac{\mathrm{d} k}{\mathrm{~d} \sigma^{*}}=\frac{\Pi_{k r^{*}}}{E}<0, \frac{\mathrm{d} r}{\mathrm{~d} \sigma^{*}}=-\frac{\Pi_{k k}}{E}>0$

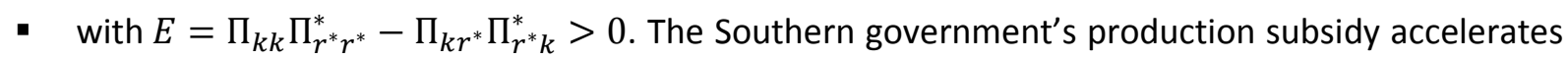
technology diffusion by increasing the Southern firm's R\&D investment and by reducing the Northern firm's patent expenditures. Such a result means that governments from developing countries can accelerate technology diffusion from rich countries by promoting domestic firm's innovations.

Note that we did not study the case where the Southern country's R\&D investment influences the date of the new technology diffusion. We could have considered a case where the Southern country implements an R\&D program at period 0 to discover the new technology as soon as possible. The monopoly period with the new technology would decrease with such an R\&D program. But the effect of the patent would be null because the Southern country could discover the new technology by itself. The issue of the model would no longer make sense in this case.

\section{An Example of "At-The-Border" Policies: The Impact of Import Tariffs}

We have studied the impact of "behind-the-border" policy instruments. Subsidies aim to promote directly domestic firms' activity. Now let us study the impact of "at-the-border" policy instruments like tariffs. They relate to traditional protectionism. They aim to reduce directly the competition from foreign countries. Even if governments often use other forms of protectionism now, tariff protection applied to imports in the agricultural sector is still high. Let us verify whether or not the results change with "at-the-border" policies.

According to previous demonstration, we can easily find the impact of tariffs on imports implemented by the Northern and the Southern governments. We denote as $t\left(t^{*}\right)$ the Northern (Southern) government's specific import tariffs. The static profit expressions are:

$$
\begin{aligned}
& \pi=x p(x+y)+x^{*} p^{*}\left(x^{*}+y^{*}\right)-c(\bar{\mu})\left(x+x^{*}\right)-\left(g+t^{*}\right) x^{*} \\
& \pi^{*}=y p(x+y)+y^{*} p^{*}\left(x^{*}+y^{*}\right)-c^{*}\left(\mu^{*}\right)\left(y+y^{*}\right)-(g+t) y, \text { with } \mu^{*}=\underline{\mu}^{*}, \bar{\mu}^{*}
\end{aligned}
$$


Tariffs have the same impact on profits as transport costs. The tariff $t\left(t^{*}\right)$ has only an impact

on the Northern (Southern) market. We can infer that domestic sales (imports) increase (decrease) with the tariff on each market. Each tariff also increases the domestic market price and reduces the domestic country's consumer surplus. The domestic (foreign) firm's profit increases (decreases) with the domestic tariff. We have:

$$
\begin{aligned}
& \frac{\mathrm{d} \widehat{\pi}\left(\mu^{*}, t, t^{*}\right)}{\mathrm{d} t}=\frac{2\left[a-2 c(\bar{\mu})+c^{*}\left(\mu^{*}\right)+g^{*}+t\right]}{9}=\frac{2 \hat{x}\left(\mu^{*}, t\right)}{3}>0, \text { with } \mu^{*}=\underline{\mu}^{*}, \bar{\mu}^{*} \\
& \frac{\mathrm{d} \widehat{\pi}\left(\mu^{*}, t, t^{*}\right)}{\mathrm{d} t^{*}}=-\frac{4\left[a^{*}-2 c(\bar{\mu})+c^{*}\left(\mu^{*}\right)-2 g-2 t^{*}\right]}{9}=-\frac{4 \hat{x}^{*}\left(\mu^{*}, t^{*}\right)}{3}<0, \text { with } \mu^{*}=\underline{\mu}^{*}, \bar{\mu}^{*}
\end{aligned}
$$

Proposition 5: Under the specific linear inverse demand functions:

- The Northern government's import tariff $t$ slows down the new technology diffusion by increasing the Northern firm's patent expenditures.

- The Southern government's import tariff $t^{*}$ accelerates the new technology diffusion by reducing the Northern firm's patent expenditures.

- The sign of the impact of import tariffs is the same as the sign of the impact of production subsidies. But the impact of production subsidies is stronger.

Proof: The positive (negative) impact of the Northern (Southern) government's tariff $t\left(t^{*}\right)$ on the Northern firm's profit increases with the Southern firm's marginal cost. Hence, the Northern (Southern) government's tariff increases (reduces) the difference in profit. Then, the Northern (Southern) government's tariff increases (reduces) the Northern firm's patent expenditures $k$ and the monopoly period $T$ and slows down (accelerates) the new technology diffusion.

The Northern government's tariff $t$ reduces the competition of the Southern firm on the Northern market. The Northern firm benefits from a higher market share on its domestic market. The positive impact of the drop in $y$ on $\pi$ increases with $x: \pi_{y}=-x<0$. The domestic sales $x$ are higher before the new technology diffusion. Then, the Northern firm is encouraged to increase its patent expenditures. Conversely, the Southern government's tariff $t^{*}$ increases the competition of the Southern firm on the Southern market. The negative impact of the rise in $y^{*}$ on $\pi$ increases with $x^{*}$ : $\pi_{y^{*}}=-x^{*}<0$. The exports $x^{*}$ are higher before the new technology diffusion. Then, the Northern firm is encouraged to reduce its patent expenditures. 
The sign the impact of an "at-the-border" policy instrument like an import tariff is the same as the sign of the impact of a "behind-the-border" policy instrument like a production subsidy. But comparing (16) to (26), and (20) to (27), the negative (positive) impact of the Northern (Southern) government's production subsidy on the speed of the new technology diffusion is stronger than the negative (positive) impact of the Northern (Southern) government's import tariff. "Behind-theborder" policy instruments seem to be more efficient.

Nevertheless, the limit of these results is the same as with production subsidies. We cannot demonstrate that the results hold under nonlinear inverse demand functions. See Appendix A.

\section{Welfare Analysis}

Previously, we have studied the impact of policy instruments on the speed of the new technology diffusion from the Northern firm to the Southern firm. Now, let us analyze the economic impact of each instrument via the effect on profits, consumer surplus, public revenues and national welfares.

\subsection{General Framework Under Free Trade}

We need to find the equilibrium expressions of profits, consumer surplus and national welfare. First, let us find the equilibrium expression of $\hat{k}$. We use a linear function for the monopoly period $T: T(k)=\theta+\omega k$. We have:

$\hat{k}=\frac{\ln \left\{\omega\left[\widehat{\pi}\left(\underline{\mu}^{*}\right)-\widehat{\pi}\left(\bar{\mu}^{*}\right)\right]\right\}-i \theta}{i \omega}$

The equilibrium expressions of discounted sum of profit flows are:

$$
\widehat{\Pi}=\frac{\omega \widehat{\pi}\left(\underline{\mu}^{*}\right)-1-\ln \left\{\omega\left[\widehat{\pi}\left(\underline{\mu}^{*}\right)-\widehat{\pi}\left(\bar{\mu}^{*}\right)\right]\right\}+i \theta}{i \omega}, \widehat{\Pi}^{*}=\frac{\left\{\omega\left[\widehat{\pi}\left(\underline{\mu}^{*}\right)-\widehat{\pi}\left(\bar{\mu}^{*}\right)\right]-1\right\} \widehat{\pi}^{*}\left(\underline{\mu}^{*}\right)+\widehat{\pi}^{*}\left(\bar{\mu}^{*}\right)}{i \omega\left[\widehat{\pi}\left(\underline{\mu}^{*}\right)-\widehat{\pi}\left(\bar{\mu}^{*}\right)\right]}
$$

The equilibrium expressions of each country's consumer surplus are:

$$
\widehat{\mathrm{CS}}=\frac{\left\{\omega\left[\widehat{\pi}\left(\underline{\mu}^{*}\right)-\widehat{\pi}\left(\bar{\mu}^{*}\right)\right]-1\right\}\left[\hat{x}\left(\underline{\mu}^{*}\right)\right]^{2}+\left[\hat{X}\left(\bar{\mu}^{*}\right)\right]^{2}}{2 i \omega\left[\widehat{\pi}\left(\underline{\mu}^{*}\right)-\widehat{\pi}\left(\bar{\mu}^{*}\right)\right]}, \widehat{\mathrm{CS}}^{*}=\frac{\left\{\omega\left[\widehat{\pi}\left(\underline{\mu}^{*}\right)-\widehat{\pi}\left(\bar{\mu}^{*}\right)\right]-1\right\}\left[\widehat{X}^{*}\left(\underline{\mu}^{*}\right)\right]^{2}+\left[\hat{X}^{*}\left(\bar{\mu}^{*}\right)\right]^{2}}{2 i \omega\left[\widehat{\pi}\left(\underline{\mu}^{*}\right)-\widehat{\pi}\left(\bar{\mu}^{*}\right)\right]}
$$

Under free trade, the national welfares are: $\widehat{\mathrm{W}}=\widehat{\Pi}+\widehat{\mathrm{CS}}, \widehat{\mathrm{W}}^{*}=\widehat{\Pi}^{*}+\widehat{\mathrm{CS}}^{*}$. 


\subsection{Discussion}

Let us study now the impact of each policy instrument on discounted sums of profit flows, consumer surplus and public revenues. PR (PR*) denotes the Northern (Southern) country's public revenues. ${ }^{5}$ Table 1 illustrates the economic impact of each policy instrument.

Table 1 - Economic Impact of Each Policy Instrument

\begin{tabular}{|c|c|c|c|c|c|c|c|}
\hline $\begin{array}{l}\text { Inst } \\
\text { rument }\end{array}$ & $T$ & $\Pi$ & $\Pi^{*}$ & CS & $\mathrm{CS}^{*}$ & PR & $\mathrm{PR}^{*}$ \\
\hline$S$ & + & + & - & + & + & - & 0 \\
\hline$\varphi$ & + & + & - & - & - & - & 0 \\
\hline$t$ & + & + & - & - & - & + & 0 \\
\hline$S^{*}$ & - & - & + & + & + & 0 & - \\
\hline$r^{*} / \sigma^{*}$ & - & - & + & + & + & 0 & - \\
\hline$t^{*}$ & - & - & + & + & - & 0 & + \\
\hline
\end{tabular}

Source: author.

The Northern government's production subsidy increases the Northern firm's discounted sum of profit flows by providing further revenues and by increasing the monopoly period with the new technology. It reduces the Southern firm's discounted sum of profit flows. There is a direct positive impact on each consumer surplus because the production subsidy increases total supplies on each market and reduces each market price: $\mathrm{d} X\left(\mu^{*}, s\right) / \mathrm{d} s=\mathrm{d} X^{*}\left(\mu^{*}, s\right) / \mathrm{d} s=1 / 3>0$, $\mathrm{d} p\left(\mu^{*}, s\right) / \mathrm{d} s=\mathrm{d} p^{*}\left(\mu^{*}, s\right) / \mathrm{d} s=-1 / 3<0$, with $\mu^{*}=\mu^{*}, \bar{\mu}^{*}$. Even if the production subsidy slows down the new technology diffusion, the total effect on each consumer surplus is positive. Finally, the production subsidy involves further public expenditures for the Northern country.

$$
\begin{aligned}
& { }^{5} \widehat{\mathrm{PR}}=\left\{\begin{array}{c}
-s \frac{\left\{\omega\left[\widehat{\pi}\left(\underline{\mu}^{*}\right)-\widehat{\pi}\left(\bar{\mu}^{*}\right)\right]-1\right\}\left[x\left(\underline{\mu}^{*}\right)+x^{*}\left(\underline{\mu}^{*}\right)\right]+\left[x\left(\bar{\mu}^{*}\right)+x^{*}\left(\bar{\mu}^{*}\right)\right]}{i \omega\left[\widehat{\pi}\left(\underline{\mu}^{*}\right)-\widehat{\pi}\left(\bar{\mu}^{*}\right)\right]}, \text { with the production subsidy } S \\
-\varphi \hat{k}, \text { with the patent subsidy } \varphi
\end{array}\right. \\
& t \frac{\left\{\omega\left[\hat{\pi}\left(\underline{\mu}^{*}\right)-\widehat{\pi}\left(\bar{\mu}^{*}\right)\right]-1\right\} y\left(\underline{\mu}^{*}\right)+y\left(\bar{\mu}^{*}\right)}{i \omega\left[\hat{\pi}\left(\underline{\mu}^{*}\right)-\widehat{\pi}\left(\bar{\mu}^{*}\right)\right]} \text {, with the tariff } t \\
& \widehat{\mathrm{PR}}^{*}=\left\{\begin{array}{c}
-s^{*} \frac{\left\{\omega\left[\widehat{\pi}\left(\underline{\mu}^{*}\right)-\widehat{\pi}\left(\bar{\mu}^{*}\right)\right]-1\right\}\left[y\left(\underline{\mu}^{*}\right)+y^{*}\left(\underline{\mu}^{*}\right)\right]+\left[y\left(\bar{\mu}^{*}\right)+y^{*}\left(\bar{\mu}^{*}\right)\right]}{i \omega\left[\widehat{\pi}\left(\underline{\mu}^{*}\right)-\widehat{\pi}\left(\bar{\mu}^{*}\right)\right]}, \text { with the production subsidy } s^{*} \\
-v r^{*}, \text { with the public Research and Development investment } r^{*}
\end{array}\right. \\
& \widehat{\mathrm{PR}}^{*}=\left\{\begin{array}{r}
-v r^{*}, \text { with the public Research and Development investment } r^{*} \\
-\sigma^{*} \hat{r}^{*} \text {, with the Research and Development subsidy } \sigma^{*}
\end{array}\right. \\
& t \frac{\left\{\omega\left[\hat{\pi}\left(\underline{\mu}^{*}\right)-\widehat{\pi}\left(\bar{\mu}^{*}\right)\right]-1\right\} y\left(\underline{\mu}^{*}\right)+y\left(\bar{\mu}^{*}\right)}{i \omega\left[\hat{\pi}\left(\underline{\mu}^{*}\right)-\hat{\pi}\left(\bar{\mu}^{*}\right)\right]} \text {, with the tariff } t
\end{aligned}
$$


firm's discounted sum of profit flows. The subsidy does not directly affect price and outputs. But the Southern firm uses the old technology for longer i.e. its marginal cost remains $c^{*}\left(\underline{\mu}^{*}\right)$ for longer. Therefore, it reduces each country's consumer surplus. It also lowers the Northern country's public revenues.

The Northern government's import tariff reduces the Southern firm's discounted sum of profit flows due to further transport costs. It increases the Northern firm's discounted sum of profit flows by reducing competition on the Northern market and by increasing the monopoly period with the new technology. It also reduces the Northern country's consumer surplus by reducing the total supplies and increasing the market price: $\mathrm{d} X\left(\mu^{*}, t\right) / \mathrm{d} t=-1 / 3<0, \mathrm{~d} p\left(\mu^{*}, t\right) / \mathrm{d} t=1 / 3>0$, with $\mu^{*}=\underline{\mu}^{*}, \bar{\mu}^{*}$. The tariff also reduces the Northern country's consumer surplus by increasing the monopoly period with the new technology. Finally, the Northern government's tariff involves further public revenues for the Northern country.

According to the impact of the Northern government's production subsidy and tariff, we can easily find the impact of the Southern government's production subsidy and tariff. The Southern government's production subsidy and tariff reduces (increases) the Northern (Southern) firm's discounted sum of profit flows. The Southern government's production subsidy (tariff) increase (reduces) each (the Southern) country's consumer and involves further public expenditures (revenues) for the Southern government. Note that the Southern government's tariff increases the Northern country's consumer surplus by reducing the monopoly period.

The Southern government's public R\&D investment/R\&D subsidy increases the Southern firm's discounted sum of profit flows by providing an intermediate technology over $[0, T)$. The Northern firm's discounted sum of profit flows decreases as compared to the initial situation without R\&D owing to the rise of the Southern firm's domestic sales and exports. Furthermore, the Northern firm is encouraged to reduce its patent expenditures. Then, the effect on each country's consumer surplus is positive. But it involves further public expenditures for the Southern government.

\subsection{Optimal Policy Instruments Under Numerical Simulations}


According to the economic impact of each policy instrument, we have to verify whether or not governments are encouraged to implement it. Let us study the impact on national welfares $W$ and $W^{*}$. We can also compare each instrument. Table 2 illustrates the optimal level of each instrument and the effect of national welfares as compared to free trade. The results are obtained under numerical simulations because analytical demonstrations seem too complex. Note that we only study the impact of a public R\&D investment because it seems complex to find the equilibrium expressions of $k$ and $r^{*}$ by considering a private R\&D investment. We use a linear marginal cost function: $c^{*}\left[\mu_{r^{*}}^{*}\left(r^{*}\right)\right]=c^{*}\left(\bar{\mu}^{*}\right)+\lambda /\left(1+r^{*}\right)$, with $\lambda>0$.

Table 2 - Optimal Policy Instruments

\begin{tabular}{|c|c|c|c|}
\hline Instrument & Optimal Value & $\Delta \mathrm{W}$ & $\Delta \mathrm{W}^{*}$ \\
\hline$s$ & 23.83143 & 2207.07 & -188.345 \\
\hline$\varphi$ & -1.29851 & 2.673249 & 31.61952 \\
\hline$t$ & 13.3405203 & 890.148321 & -1353.01039 \\
\hline$s^{*}$ & 18.90357 & -715.086 & 1355.385 \\
\hline$r^{*}$ & 15.7495281 & -396.024179 & 2179.44502 \\
\hline$t^{*}$ & 11.1251019 & -1174.78568 & 614.817801 \\
\hline
\end{tabular}

Source: author.

Note: $\quad a=50, a^{*}=40, c(\bar{\mu})=6, c^{*}\left(\underline{\mu}^{*}\right)=9, c^{*}\left(\bar{\mu}^{*}\right)=3, g=g^{*}=1, \theta=5, \omega=1, i=$ $0.1, v^{*}=10, \lambda=9$

Appendix B illustrates the results when the value of parameters varies. According to these results, we conclude that:

- The Northern government is encouraged to implement a production subsidy or an import tariff because their optimal levels are positive. They increase the Northern country's national welfare. The Northern government's tariff always reduces the Southern country's national welfare. But the Northern government's production subsidy may increase the Southern country's national welfare. The positive effect on the consumer surplus may be stronger than the negative effect on the discounted sum of profit flows. Nevertheless, the production subsidy $s$ often reduces the Southern country's national welfare. 
- The Southern government is also encouraged to implement a production subsidy or a tariff for the same reason. They increase (reduce) the Southern (Northern) country's national welfare. We do not find any case where the Southern government's production subsidy increases the Northern country's national welfare.

- The Northern government is encouraged to tax its domestic firm's patent expenditures because the optimal patent subsidy is negative. Such results mean that patents engender a cost for the Northern country's national welfare. This is in complete contrast to several previous studies that establish the existence of an optimal patent length. The main reason for this is that the Northern firm does not invest in its technological advantage. This implies that the patent reduces the Northern country's consumer surplus while the further public expenditures offset the positive effect on the Northern firm's profit.

- The Southern government is encouraged to implement a public R\&D program because the optimal level of public R\&D is positive. It increases (reduces) the Southern (Northern) country's national welfare.

- The Northern country's favorite policy instrument is the production subsidy. We have: $s>t>$ $\varphi$, where $>$ denotes the Northern government's preference. The positive effect of the production subsidy is stronger than the positive effect of the tariff: (i) the production subsidy involves a direct positive impact on the Northern firm's profit flows while the effect of the tariff is indirect by reducing the competition on the Northern market, (ii) the positive effect of the production subsidy on the consumer surplus is stronger than the tariff revenues. Finally, the optimal patent subsidy maximizes the consumer surplus because the discounted sum of profit flows minus the public expenditures equals to the discounted sum of profit flows under free trade: $\Pi(k, \varphi)-\varphi k=\Pi(k)$. Then, the optimal subsidy is negative but its impact on the national welfare is lower than the impacts of the production subsidy and of the tariff.

- The Southern country's favorite policy instrument is the public R\&D investment. We have: $r^{*}>s^{*}>t^{*}$. The public R\&D increases the Southern firm's discounted profit by providing an intermediate technology over $[0, T)$. The difference with respect to the production subsidy is that the Southern government only incurs the R\&D cost at period 0 . 
An important result is that the patent subsidy is not optimal because the Northern government is encouraged to implement a patent tax. Now, we study the case where the Northern firm invests in its technological advantage with the patent to verify whether or not a patent subsidy may become optimal.

\section{Investment in Technological Advantage}

Patents imply protection for the Northern firm. They then imply a technological advantage. We previously found that the Northern government's patent subsidy is not optimal with respect to the Northern country's national welfare. We wish to verify whether or not such a subsidy might become optimal when the Northern firm invests in its technological advantage. As we said in the general introduction, empirically speaking, there is a growing interest in patent subsidies. But it would be interesting to ascertain whether or not this investment in technological advantage is a condition whereby the said public policy may help to increase the domestic country's national welfare. We omit the case of a public R\&D investment/R\&D subsidy because the Northern government already subsidizes the patent expenditures.

Here, we consider that the Northern firm invests in such a technological advantage by implementing an R\&D investment in processes in order to increase its profit flows at each point in time by decreasing its marginal cost $c$. The Northern firm's R\&D investment depends on the technological advantage, i.e. the patent expenditures $k: r=r(k)$. The Northern firm's marginal cost depends on $r(k): c=c[r(k), \bar{\mu}]$. We are going to demonstrate that the cost-reducing R\&D increases the Northern firm's profit flows and that the patent expenditures $k$ also increase the said profit flows. This can be a form of what economic literature calls the patent breadth.

Assumption 8: The Northern firm's R\&D investment increases with $k: r^{\prime}(k)=\partial r(k) / \partial k>$ 0 . Consider a concave function: $r^{\prime \prime}(k) \leq 0$. The Northern firm only implements the R\&D investment at period 0 .

We use the following concave function of R\&D: $r=k^{\beta}$, with $0<\beta<1$, where $\beta$ denotes the constant elasticity of the Northern firm's R\&D investments with respect to its patent expenditures. 
Assumption 9: The Northern firm's marginal cost decreases with its R\&D investment:

$\partial c[r(k), \bar{\mu}] / \partial r(k)<0$. However, the returns are decreasing: $\partial^{2} c[r(k), \bar{\mu}] / \partial r(k)^{2} \geq 0$ (Brander and Spencer, 1983). The Northern firm's R\&D investment influences its marginal cost over $[0, \infty)$. This marginal cost stays constant throughout the interval.

We use the following concave function of marginal cost: $c[r(k), \bar{\mu}]=\gamma(\bar{\mu}) / r(k)$, where $\gamma(\bar{\mu})$ denotes the constant part of the marginal cost that does not depend on the R\&D investment. We denote as $v$ the unit cost of R\&D. Then, the term $\operatorname{vr}(k)$ denotes the total value of the cost of R\&D that appears in the discounted sum of profit flows but not in static profit flows. The Northern firm's static profit expression is:

$$
\pi=x p(x+y)+x^{*} p^{*}\left(x^{*}+y^{*}\right)-c[r(k), \bar{\mu}]\left(x+x^{*}\right)-g x^{*}
$$

We have already studied the impact of $c^{*}$ on outputs, price and profits in section 2 . We can easily find each impact of $c$. Then, the R\&D investment increases (reduces) the Northern (Southern) firm's domestic sales and exports, reduces the market prices and increases (reduces) the Northern (Southern) firm's profit.

The integrated dynamic program with the Northern government's patent subsidy $\varphi$ becomes:

$$
\max _{k \geq 0} \Pi(k)=\frac{\left[1-e^{-i T(k)}\right] \hat{\pi}\left[r(k), \underline{\mu}^{*}\right]+e^{-i T(k)} \hat{\pi}\left[r(k), \bar{\mu}^{*}\right]}{i}-[k(1-\varphi)+\operatorname{vr}(k)]
$$

We can easily demonstrate that the patent subsidy still increases the Northern firm's patent expenditures $k$ by reducing the total value of the patent filing cost. Then, the Northern firm is encouraged to increase its $R \& D$ investment with the said subsidy. We now study the impact of the patent subsidy on the Northern country's national welfare. Figure 2 illustrates the evolution of the optimal patent subsidy when the parameter $\beta$ varies. 
Figure 2 - Evolution of The Optimal Patent Subsidy $\widehat{\varphi}$ When $\beta$ Varies

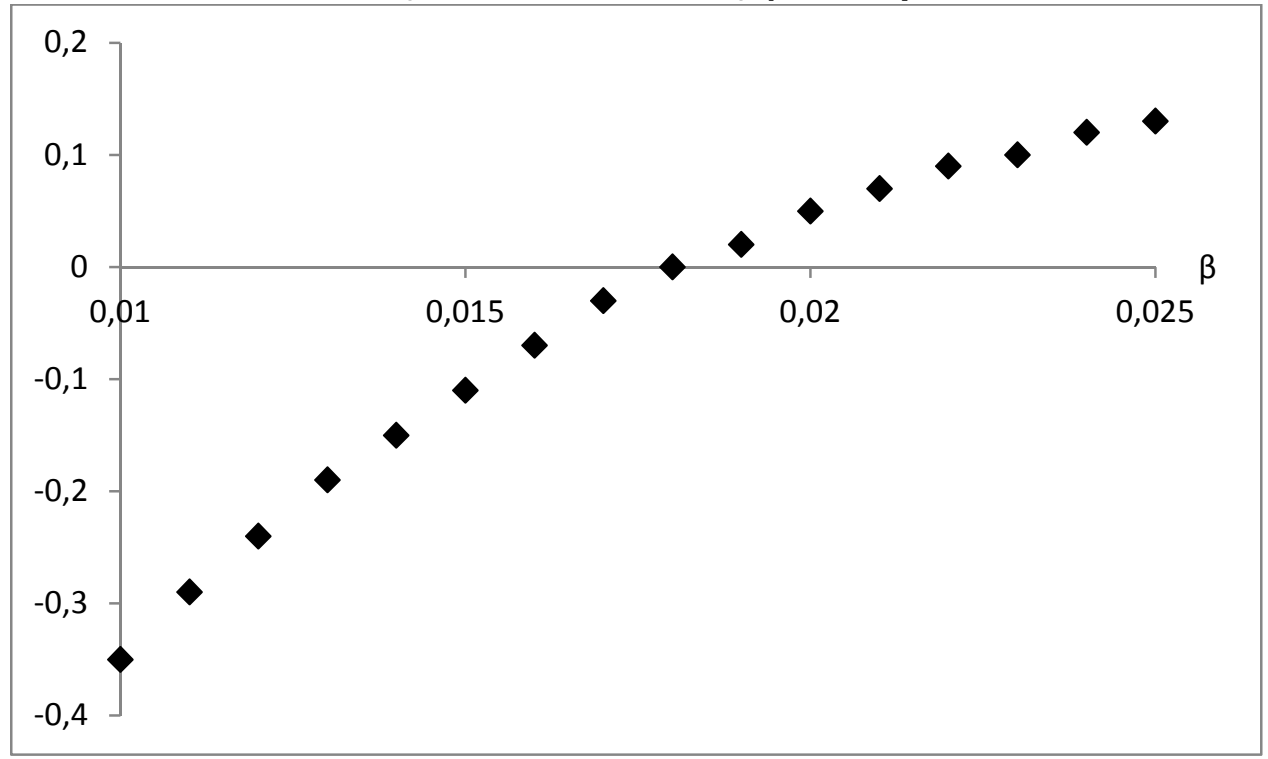

Source: author

Note: $\quad a=50, a^{*}=40, c(\bar{\mu})=6, c^{*}\left(\underline{\mu}^{*}\right)=9, c^{*}\left(\bar{\mu}^{*}\right)=3, g=g^{*}=1, \theta=5, \omega=1, i=$ $0.1, \gamma(\bar{\mu})=6, v=10$.

The effect of a patent subsidy on the Northern country's national welfare is now uncertain. We find cases where the patent subsidy increases the Northern country's national welfare. Note that the results depend on the value of the elasticity $\beta$ of the Northern firm's R\&D investment with respect to its patent expenditures $k$. The optimal patent subsidy that maximizes the Northern country's national welfare becomes positive if $\beta>0.018$. A patent tax is still optimal, otherwise. The reason is that the result strongly depends on the sensitivity of the Northern firm's R\&D investment with respect to its patent expenditures. Note that such a result is of great value for understanding the reason for the increasing interest for patent subsidy. Such a subsidy is optimal only if the firm that files the patent invests in its technological advantage. Furthermore, the results also permit to understand that patents increase national welfare only if patentee firms invest in their technological advantage. 


\section{Bertrand Competition}

Consider now Bertrand competition at each point in time. Let us study whether or not the results hold under price competition. The second stage in Figure 1 is modified. Now, firms select the optimal level of prices.

\subsection{The Impact of Policy Instruments on The Speed of The New Technology Diffusion}

Assumption 10: Firms produce slightly differentiated goods to avoid a "Bertrand paradox." We denote as $p_{n}\left(p_{n}^{*}\right)$ the Northern (Southern) firm's price on the Northern market and $p_{s}\left(p_{S}^{*}\right)$ the Southern firm's price on the Southern market. Domestic sales and exports depend on prices: $x=x\left(p_{n}, p_{n}^{*}\right), x^{*}=x^{*}\left(p_{s}, p_{s}^{*}\right), y=y\left(p_{n}, p_{n}^{*}\right), y^{*}=y^{*}\left(p_{s}, p_{s}^{*}\right)$. Domestic sales and exports decrease (increase) with domestic (foreign) prices: $x_{p_{n}}<0, x_{p_{s}}^{*}<0, x_{p_{n}^{*}}>0, x_{p_{s}^{*}}^{*}>0, y_{p_{n}}>0, y_{p_{s}}^{*}>0$, $y_{p_{n}^{*}}<0, y_{p_{s}^{*}}^{*}<0$. Own effects are stronger than cross effects: $\left|x_{p_{n}}\right|>x_{p_{n}^{*}},\left|x_{p_{s}}^{*}\right|>x_{p_{s}^{*}}^{*}, y_{p_{n}}<\left|y_{p_{n}^{*}}\right|$, $y_{p_{s}}^{*}<\left|y_{p_{s}^{*}}^{*}\right|$

The static profit expressions are:

$\pi\left(p_{n}, p_{s}, p_{n}^{*}, p_{s}^{*}\right)=p_{n} x\left(p_{n}, p_{n}^{*}\right)+p_{s} x^{*}\left(p_{s}, p_{s}^{*}\right)-c(\bar{\mu})\left[x\left(p_{n}, p_{n}^{*}\right)+x^{*}\left(p_{s}, p_{s}^{*}\right)\right]-g x^{*}\left(p_{s}, p_{s}^{*}\right)$

$\pi^{*}\left(p_{n}, p_{s}, p_{n}^{*}, p_{s}^{*}\right)=p_{n}^{*} y\left(p_{n}, p_{n}^{*}\right)+p_{s}^{*} y^{*}\left(p_{s}, p_{s}^{*}\right)-c^{*}\left(\mu^{*}\right)\left[y\left(p_{n}, p_{n}^{*}\right)+y^{*}\left(p_{s}, p_{s}^{*}\right)\right]-$ $g^{*} y\left(p_{n}, p_{n}^{*}\right)$, with $\mu^{*}=\underline{\mu}^{*}, \bar{\mu}^{*}$

Firms select the optimal level of prices instead of domestic sales and exports. We use specific linear demand functions: $x\left(p_{n}, p_{n}^{*}\right)=a-b p_{n}+p_{n}^{*}, x^{*}\left(p_{s}, p_{s}^{*}\right)=a^{*}-b^{*} p_{s}+p_{s}^{*}, y\left(p_{n}, p_{n}^{*}\right)=a+$ $p_{n}-b p_{n}^{*}, y^{*}\left(p_{s}, p_{s}^{*}\right)=a^{*}+p_{s}-b^{*} p_{s}^{*}$, with $b, b^{*}>1$. Set $c=c(\mu)$ and $c^{*}=c^{*}\left(\mu^{*}\right)$ to simplify the expressions. The equilibrium levels of price are:

$$
\begin{gathered}
\hat{p}_{n}=\frac{a(2 b+1)+2 b^{2} c+b c^{*}+b g^{*}}{4 b^{2}-1}, \hat{p}_{s}=\frac{a^{*}\left(2 b^{*}+1\right)+2 b^{* 2} c+b^{*} c^{*}+2 b^{* 2} g}{4 b^{* 2}-1}, \hat{p}_{n}^{*}= \\
\frac{a(2 b+1)+b c+2 b^{2} b c^{*}+2 b^{2} g^{*}}{4 b^{2}-1}, \hat{p}_{s}=\frac{a^{*}\left(2 b^{*}+1\right)+b c+2 b^{* 2} c^{*}+b^{*} g}{4 b^{* 2}-1}
\end{gathered}
$$

The equilibrium levels of domestic sales and exports are: 
$\hat{x}=\frac{b\left[a(2 b+1)-\left(2 b^{2}-1\right) c+b c^{*}+b g^{*}\right]}{4 b^{2}-1}, \hat{x}^{*}=\frac{b^{*}\left[a\left(2 b^{*}+1\right)-\left(2 b^{* 2}-1\right) c+b^{*} c^{*}-\left(2 b^{* 2}-1\right) g\right]}{4 b^{* 2}-1}, \hat{y}=$

$\frac{b\left[a(2 b+1)+b c-\left(2 b^{2}-1\right) c^{*}-\left(2 b^{2}-1\right) g^{*}\right]}{4 b^{2}-1}, \hat{y}^{*}=\frac{b^{*}\left[a\left(2 b^{*}+1\right)+b^{*} c-\left(2 b^{* 2}-1\right) c^{*}+b^{*} g\right]}{4 b^{* 2}-1}$

The equilibrium static profits are:

$$
\begin{gathered}
\hat{\pi}=\frac{b\left[a(2 b+1)-\left(2 b^{2}-1\right) c+b c^{*}+b g^{*}\right]^{2}}{\left(4 b^{2}-1\right)^{2}}+\frac{b^{*}\left[a\left(2 b^{*}+1\right)-\left(2 b^{* 2}-1\right) c+b^{*} c^{*}-\left(2 b^{* 2}-1\right) g\right]^{2}}{\left(4 b^{* 2}-1\right)^{2}}, \hat{\pi}^{*}= \\
\frac{b\left[a(2 b+1)+b c-\left(2 b^{2}-1\right) c^{*}-\left(2 b^{2}-1\right) g^{*}\right]^{2}}{\left(4 b^{2}-1\right)^{2}}+\frac{b^{*}\left[a\left(2 b^{*}+1\right)+b^{*} c-\left(2 b^{* 2}-1\right) c^{*}+b^{*} g\right]^{2}}{\left(4 b^{* 2}-1\right)^{2}}
\end{gathered}
$$

Let us study the impact of each policy instrument on the patent expenditures $k$. Note that the impacts of the Northern government's patent subsidy and of the Southern government's public $R \& D / R \& D$ subsidy are the same as under Cournot competition because these instruments are implemented at period 0 . Then, we only analyze the impact of production subsidies and import tariffs. The domestic production subsidy (foreign import tariff) has the same impact as a drop (rise) of the domestic marginal cost. The foreign production subsidy (domestic import tariff) has the same impact as a drop (rise) of the foreign marginal cost. The Northern firm's static profit decreases (increases) with the Northern (Southern) firm's marginal cost. We have:

$$
\frac{\mathrm{d} \hat{\pi}}{\mathrm{d} c}=-\frac{2\left(2 b^{2}-1\right) \hat{x}}{\left(4 b^{2}-1\right)}-\frac{2\left(2 b^{* 2}-1\right) \hat{x}^{*}}{\left(4 b^{* 2}-1\right)}<0, \frac{\mathrm{d} \hat{\pi}}{\mathrm{d} c^{*}}=\frac{2 b \hat{x}}{\left(4 b^{2}-1\right)}+\frac{2 b^{*} \hat{x}^{*}}{\left(4 b^{* 2}-1\right)}>0
$$

Proposition 6: Under Bertrand competition, the Northern (Southern) government's production subsidy and import tariff slow down (accelerates) the new technology by increasing (reducing) the patent expenditures $k$ and the monopoly period $T$.

Proof: According to Equation (33), the Northern firm's domestic sales and exports increase with the Southern firm's marginal cost. Then, according to Equation (35), the positive (negative) impact of the Northern (Southern) government's production subsidy and import tariff on the Northern firm's profit is stronger when the Southern firm uses the old technology. The Northern (Southern) government's production subsidy and import tariff increase (decrease) the difference in profit, the patent expenditures $k$ and the monopoly period $T$.

Unfortunately, we have the same problem as under Cournot competition. We cannot demonstrate that these results hold with general forms for demand functions. The results hold under any other linear demand function. But the results are uncertain under nonlinear demand functions due to second order effects. See Appendix C. Nevertheless, we do not find any nonlinear example 
where the Northern (Southern) government's policy instruments reduce (increase) the difference in profit.

\subsection{Welfare Analysis With Numerical Simulations Under Bertrand Competition}

Table 3 illustrates the optimal level of each instrument and the effect of national welfares as compared to free trade under Bertrand competition. Note that we omit the case where the Northern firm invests in its technological advantage.

Table 3 - Optimal Policy Instruments Under Bertrand Competition

\begin{tabular}{|c|c|c|c|}
\hline Instrument & Optimal Value & $\Delta \mathrm{W}$ & $\Delta \mathrm{W}^{*}$ \\
\hline$s$ & 4.74379099 & 170.883363 & -146.224148 \\
\hline$\varphi$ & -2.123734 & 4.59158391 & 86.438732 \\
\hline$t$ & 19.505192 & 2519.8887 & -3018.37355 \\
\hline$s^{*}$ & 2.24546229 & -123.065504 & 38.2828337 \\
\hline$r^{*}$ & 18.2521244 & -223.62071 & 2973.13151 \\
\hline$t^{*}$ & 15.2859748 & -2191.21365 & 1539.94981 \\
\hline
\end{tabular}

Source: author.

Note: $\quad a=50, a^{*}=40, b=b^{*}=2, c(\bar{\mu})=6, c^{*}\left(\underline{\mu}^{*}\right)=9, c^{*}\left(\bar{\mu}^{*}\right)=3, g=g^{*}=1, \theta=$ $5, \omega=1, i=0.1, v^{*}=10, \lambda=9$.

Appendix D illustrates the results when the value of parameters varies. The main results generally hold under Bertrand competition. Each government is encouraged to implement a production subsidy and an import tariff. The Southern government is also encouraged to invest in public R\&D. The Northern government is still encouraged to tax patent expenditures when the Northern firm does not invest in its technological advantage. But now, the Northern government's favorite policy instrument is the import tariff. We have now: $t>s>\varphi$. The positive (negative) effect of the production subsidy (import tariff) on the Northern country's consumer surplus is now lower than the tariff revenues (public expenditures). The Southern government's favorite policy instrument often remains the public R\&D investment: $r^{*}>t^{*}>s^{*}$. But, the import tariff becomes the favorite instrument under some cases. See Appendix D. There is a stronger interest for import tariffs for governments as compared to Cournot competition. The reason is that price competition is stronger 
than output competition. The levels of exports (prices) are stronger (lower) than under Cournot

(Cheng, 1985; Vives, 1985; Qiu, 1997). Tariffs lead to strong public revenues.

\section{Concluding Remarks}

The objective of this paper is to study the impact of public policy instruments on technology diffusion in a dynamic North-South model. Here we have explored a case where the Northern firm implements a patent in order to increase the monopoly period with the new technology. Then, we demonstrate that developing countries can accelerate technology diffusion by implementing policy instruments. However, developed countries can slow it down in exactly the same way. Now, if developed countries aim to help developing countries by accelerating technology diffusion, liberalization is one way to do it. Then, the role of the WTO via a TRIPs agreement and trade liberalization is crucial to promote access to technological information for developing countries.

An important result relates to the welfare impact of the Northern country's patent subsidy. We demonstrate that patent tax is optimal under the initial structure. But when the Northern firm invests in its technological advantage by implementing R\&D investment, patent subsidy may become optimal. It helps to better understand the growing interest in this type of public policy. The condition why such an instrument increases national welfare is that the patentee firm invests in its technological advantage.

Note that, in this paper, we omit externalities of technology diffusion in developing countries in the welfare analysis in order to study a simple case. Sometimes, negative externalities appear. For example, there is a cost for unskilled labor because modern technologies require that firms in developing countries hire skilled labor. Another example is the environment. Technology diffusion may create pollution in developing countries.

Last, let us mention a few directions in which we might possibly extend this model. It would be interesting to analyze the relationship between public policies and technology by considering innovation in terms of product rather than process. We might also consider other forms of technology protection such as trade secret that also make it possible to increase the monopoly period with a new technology. 
The author would like to thank an anonymous referee and the participants at the LAREFI Seminar in Bordeaux (France), the $5^{\text {th }}$ GRETHA International Conference on Economic Development in Bordeaux, and the EDEHN $2^{\text {nd }}$ PhD Student Conference on Public Policy Analysis in Le Havre (France) for their comments. Of course, any error would be his, not theirs. The author is also grateful for a Research Grant from the French Ministry of Research. 
Adenle, A. A., Sowe, S. K., Parayil, G., Aginam, O., 2012. Analysis of open source biotechnology in developing countries: an emerging framework for sustainable agriculture. Technology in Society. 34(3), 256-269.

Aitken, B., Harrisson, H., 1999. Do domestic firms benefit from foreign direct investment? Evidence from Venezuela. American Economic Review. 89(3), 605-618.

Alendete-Saez, M., Chi-Ham, C., Graff, G. D., Bennett, A. B., 2014. Intellectual property in agriculture. In: Van Alfen, B. K., 2014 (ed.). Encyclopedia of Agriculture and Food Systems. Elsevier, Oxford. 4, 31-43.

Battisti, G., 2008. Innovations and the economics of new technology spreading within and across users: gaps and way forward. Journal of Cleaner Production. 16(1), S22-S31.

Bottazi, L., Peri, G., 2003. Innovation, demand and knowledge spillovers: evidence from European patent data. European Economic Review. 47(4), 687-710.

Brander, J. A., Spencer, B. J., 1983. Strategic commitment with R\&D: the symmetric case. The Bell Journal of Economics. 14(1), 225-235.

Branstetter, L., 2001. Are knowledge spillovers international or intra-national in scope? Microeconomic evidence from the US and Japan. Journal of International Economics. 53(1), 53-79.

Cheng, L. K., 1985. Comparing Cournot and Bertrand equilibria: a geometric approach. The RAND Journal of Economics. 16(1), 146-152.

Cheng, L. K., 1987. Optimal trade and technology policies: dynamic linkages. International Economic Review. 28(3), 757-776.

Coe, D. T., Helpman E., 1995. International R\&D spillovers. European Economic Review. 39(5), 859887.

Eaton, J., Kortum, S., 1999. International patenting and technology diffusion: theory and measurement. International Economic Review. 40(3), 537-570.

Eaton, J., Kortum, S., 2002. Technology, geography, and trade. Econometrica. 70(5), 1741-1779.

Ethier, W. J., Markusen, J. R., 1996. Multinational firms, technology diffusion and trade. Journal of International Economics. 41(1-2), 1-28.

Evenett, S. J., 2013. Protectionism's quiet return. Centre for Economic Policy Research. Global Trade Alert. GTA's Pre-G8 Summit Report.

Fosfuri, A., Motta, M., Rønde, T., 2001. Foreign direct investment and spillovers through workers' mobility. Journal of International Economics. 53(1), 205-222.

Fulginiti, L. E., Perrin, R. K., 1999. Have price policies damaged LDC agricultural productivity? Contemporary Economic Policy. 17(4), 469-475.

Gallini, N. T., 1992. Patent policy and costly imitation. The RAND Journal of Economics. 23(1), 52-63.

Geroski, P. A., 2000. Models of technology diffusion. Research Policy. 29(4-5), 603-625.

Gilbert, R., Shapiro, C., 1990. Optimal patent length and breadth. The RAND Journal of Economics. 21(1), 106-112.

Griffith, R., Redding, S., Simpson, H., 2003. Productivity convergence and foreign ownership at the establishment level. CEPR Working Paper. 3765.

Griliches, Z., Hausman, J., 1986. Errors in variables in panel data. Journal of Econometrics. 31(1), 93118.

Grossman, G. M., Helpman, E., 1991. Trade, knowledge spillovers, and growth. European Economic Review. 35(2-3), 517-526.

Irwin, D., Klenow, P., 1994. Learning-by-doing spillovers in the semi-conductor industry. Journal of Political Economy. 102(6), 1200-1227.

Jaffe, A., Trajtenberg, M., Henderson, R., 1993. Geographic localization of knowledge spillovers as evidenced by patent citations. Quaterly Journal of Economics. 108(3), 577-598.

Keller, W., 2002. Geographic localization of international technology diffusion. The American Economic Review. 92(1), 120-142.

Keller, W., 2004. International technology diffusion. Journal of Economic Literature. 42, 752-782.

Klemperer, P., 1990. How broad should the scope of patent protection be? The RAND Journal of Economics. 21(1), 113-130.

Markusen, J. R., 2002. Multinational Firms and the Theory of International Trade. Cambridge, MIT Press. 
Mathew, A. J., Mukherjee, A., 2014. Intellectual property rights, Southern innovation and foreign direct investment. International Review of Economics and Finance. 31, 128-137.

Miyagiwa, K., Ohno, Y., 1997. Strategic R\&D policy and appropriability. Journal of International Economics. 42(1-2), 125-48.

Munari, F., Xu, L., 2011. Are patent subsidies for SMEs effective? Empirical evidence from Italy. 6th Annual Conference of the European Policy for Intellectual Property Association.

Nordhaus, W. D., 1969. An economic theory of technological change. American Economic Review. 59(2), 18-28

O'Neill, D. H., 2000. Ergonomics in industrially developing countries: does its application differ from that in industrially advanced countries? Applied Ergonomics. 31(6), 631-640.

Pakes, A., 1996. Patents as options: some estimates of the value of holding European patent stocks. Econometrica. 54(4), 755-784.

Qiu, L. D., 1997. On the dynamic efficiency of Bertrand and Cournot equilibria. Journal of Economic Theory. 75(1), 213-229.

Reppelin-Hill, V., 1999. Trade and environment: an empirical analysis of the technology effect in the steel industry. Journal of Environmental Economics and Management. 38(3), 283-301.

Rivera-Batiz, L., Romer, P., 1991. Economic integration and endogenous growth. Quaterly Journal of Economics. 106(2), 531-555.

Scherer, F. M., 1972. Nordhaus' theory of optimal patent life: a geometric reinterpretation. The American Economic Review. 62(3), 422-427.

Spencer, B. J., Brander, J. A., 1983. International R\&D rivalry and industrial strategy. Review of Economic Studies. 50(4), 702-722.

Tandon, P., 1982. Optimal patent with compulsory licensing. Journal of Political Economy. 90(3), 470486.

UNCTAD, 2011. Foreign direct investment, the transfer and diffusion of technology, and sustainable development. UNCTAD Secretariat. United Nations Publications. Geneva.

Vives, X., 1985. On the efficiency of Bertrand and Cournot equilibria with product differentiation. Journal of Economic Theory. 36(1), 166-175. 


\section{A. General Forms For Inverse Demand Functions}

Using general forms, we have:

$$
\begin{aligned}
& \frac{\mathrm{d} \hat{\pi}}{\mathrm{d} s}=\frac{\hat{x} \pi_{x x} \pi_{y y}^{*}}{D}+\frac{\hat{x}^{*} \pi_{x^{*} x^{*} \pi_{y^{*} y^{*}}^{*}}}{D^{*}}>0, \text { with } \mu^{*}=\underline{\mu}^{*}, \bar{\mu}^{*} \\
& \frac{\mathrm{d} \hat{\pi}}{\mathrm{d} s^{*}}=-\left(\frac{\hat{x} \pi_{x x} \pi_{x y}}{D^{*}}+\frac{\left.\hat{x}^{*} \pi_{x^{*} x^{*} \pi_{x^{*} y^{*}}}^{D^{*}}\right)<0, \text { with } \mu^{*}=\underline{\mu}^{*}, \bar{\mu}^{*}}{\frac{\mathrm{d} \hat{\pi}}{\mathrm{d} t}=\frac{\hat{x} \pi_{x x} \pi_{x y}}{D}>0, \text { with } \mu^{*}=\underline{\mu}^{*}, \bar{\mu}^{*}}\right. \\
& \frac{\mathrm{d} \hat{\pi}}{\mathrm{d} t^{*}}=-\frac{\hat{x}^{*} \pi_{x^{*} x^{*} \pi_{y^{*} y^{*}}^{*}}<0, \text { with } \mu^{*}=\underline{\mu}^{*}, \bar{\mu}^{*}}{D^{*}}
\end{aligned}
$$

Under linear demand function, the only terms which depend on $\mu^{*}$ are $\hat{x}$ and $\hat{x}^{*}$. In Section 2 , we proved that the Northern firm's domestic sales and exports increase with the Southern firm's marginal cost. The positive (negative) effect of $s$ and $t\left(s^{*}\right.$ and $\left.t^{*}\right)$ on $\pi$ is stronger when the Southern firm uses the old technology $\mu^{*}=\underline{\mu}^{*}$. The production subsidy and the tariff implemented by the Northern (Southern) government increase (reduce) the difference in profit. But under nonlinear demand function, it is complex to find general results because each term depends on $\mu^{*}$. In this case, each instrument may increase or decrease the difference in profit. Nevertheless, we did not find any nonlinear example where the effects of $s$ and $t\left(s^{*}\right.$ and $\left.t^{*}\right)$ are negative (positive). Then, the

\begin{tabular}{|c|c|c|c|c|}
\hline 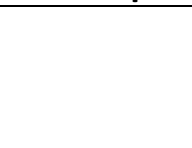 & $\begin{array}{l}\text { Instrume } \\
\text { nt }\end{array}$ & $\begin{array}{l}\text { Optimal } \\
\text { Value }\end{array}$ & $\Delta \mathrm{W}$ & $\Delta \mathrm{W}^{*}$ \\
\hline \multirow[t]{4}{*}{$\Delta a^{*}=10$} & $S$ & 25.26310 & 2480.733 & $\begin{array}{c}- \\
97.9177169\end{array}$ \\
\hline & $\varphi$ & -1 & 1.931471 & 25.00001 \\
\hline & $t$ & 13.34064 & 890.1210 & $\begin{array}{c}- \\
1352.15508\end{array}$ \\
\hline & $s^{*}$ & 23.22446 & - & 2048.370 \\
\hline
\end{tabular}
production subsidy generally slows down technology diffusion.

\section{B. Numerical Simulations for The Welfare Analysis}

Table 4 - Optimal Policy Instruments When Parameters Vary 


\begin{tabular}{|c|c|c|c|c|}
\hline & & 19 & 1117.61577 & 46 \\
\hline & $r^{*}$ & $\begin{array}{l}16.90909 \\
4\end{array}$ & $\begin{array}{c}- \\
522.837417\end{array}$ & 2555.756 \\
\hline & $t^{*}$ & $\begin{array}{l}14.46230 \\
77\end{array}$ & $\begin{array}{c}- \\
1956.33697\end{array}$ & 1039.590 \\
\hline \multirow[t]{6}{*}{$\Delta a^{*}=20$} & $s$ & $\begin{array}{l}26.69417 \\
17\end{array}$ & $\begin{array}{l}2770.127 \\
8\end{array}$ & 3.858251 \\
\hline & $\varphi$ & $\begin{array}{c}- \\
0.81308485\end{array}$ & $\begin{array}{l}1.465757 \\
16\end{array}$ & 20.74623 \\
\hline & $t$ & $\begin{array}{ll} & 13.34061 \\
52 & \end{array}$ & $\begin{array}{l}890.0804 \\
13\end{array}$ & $\begin{array}{c}- \\
1351.43278\end{array}$ \\
\hline & $s^{*}$ & 27.53956 & $\begin{array}{c}- \\
1608.83141\end{array}$ & 2883.815 \\
\hline & $r^{*}$ & 17.99724 & $\begin{array}{c}- \\
650.289281\end{array}$ & 2933.596 \\
\hline & $t^{*}$ & $\begin{array}{l}17.79794 \\
97\end{array}$ & $\begin{array}{c}- \\
\\
2935.58451\end{array}$ & 1575.260 \\
\hline \multirow[t]{6}{*}{$\Delta c^{*}\left(\underline{\mu}^{*}\right)=-3$} & $S$ & 23.40164 & 2127.971 & $\begin{array}{c}- \\
760.945292\end{array}$ \\
\hline & $\varphi$ & $\begin{array}{c}- \\
1.48739497\end{array}$ & $\begin{array}{l}3.132629 \\
88\end{array}$ & 40.25011 \\
\hline & $t$ & 14.34004 & $\begin{array}{l}1028.538 \\
23\end{array}$ & $\begin{array}{c}- \\
1773.75271\end{array}$ \\
\hline & $s^{*}$ & 21.33871 & $\begin{array}{c}- \\
303.562419\end{array}$ & 1697.326 \\
\hline & $r^{*}(\mathrm{a})$ & 10.86894 & $\begin{array}{c}- \\
158.107414\end{array}$ & 1109.955 \\
\hline & $t^{*}$ & 11.14983 & - & 616.5597 \\
\hline
\end{tabular}




\begin{tabular}{|c|c|c|c|c|}
\hline & & 57 & 1027.06103 & 65 \\
\hline \multirow{12}{*}{$\Delta c^{*}\left(\underline{\mu}^{*}\right)=3$} & \multirow{2}{*}{$s$} & & \multirow[t]{2}{*}{2281.388} & 303.0726 \\
\hline & & 22.9999 & & 01 \\
\hline & \multirow{2}{*}{$\varphi$} & - & \multirow[t]{2}{*}{2.299996} & \multirow[t]{2}{*}{25.06900} \\
\hline & & 1.14765101 & & \\
\hline & \multirow[t]{2}{*}{$t$} & 12.34094 & \multirow[t]{2}{*}{761.7476} & \multirow[b]{2}{*}{976.840376} \\
\hline & & 55 & & \\
\hline & \multirow[t]{2}{*}{$s^{*}$} & \multirow[t]{2}{*}{16.60851} & - & \multirow[t]{2}{*}{1055.408} \\
\hline & & & 1012.86461 & \\
\hline & \multirow[t]{2}{*}{$r^{*}(\mathrm{a})$} & \multirow[t]{2}{*}{19.48016} & - & \multirow[t]{2}{*}{3101.726} \\
\hline & & & 686.806899 & \\
\hline & \multirow[t]{2}{*}{$t^{*}$} & \multirow[t]{2}{*}{11.10464} & - & \multirow[t]{2}{*}{613.3399} \\
\hline & & & 1322.08734 & \\
\hline \multirow[t]{12}{*}{$\Delta c(\bar{\mu})=-3$} & \multirow{2}{*}{$S$} & 25.97788 & \multirow[t]{2}{*}{2623.140} & \multirow[t]{2}{*}{387.0787} \\
\hline & & 25 & & \\
\hline & \multirow{2}{*}{$\varphi$} & - & \multirow[t]{2}{*}{1.988287} & \multirow[t]{2}{*}{20.33961} \\
\hline & & 1.02272655 & & \\
\hline & \multirow[t]{2}{*}{$t$} & 13.34050 & \multirow[t]{2}{*}{890.0916} & \multirow[b]{2}{*}{1173.44046} \\
\hline & & 91 & & \\
\hline & \multirow[t]{2}{*}{$s^{*}$} & \multirow[t]{2}{*}{18.26931} & - & \multirow[t]{2}{*}{1282.275} \\
\hline & & & 1153.14029 & \\
\hline & \multirow[t]{2}{*}{$r^{*}$} & \multirow[t]{2}{*}{15.31908} & - & 2046.850 \\
\hline & & & 527.381622 & 31 \\
\hline & $t^{*}$ & 12.08422 & - & 727.3784 \\
\hline & & 26 & 1547.9453 & 12 \\
\hline$\Delta c(\bar{\mu})=3$ & & 21.68371 & 1826.477 & - \\
\hline & & 47 & 82 & 667.883238 \\
\hline & $\varphi$ & - & 3.927392 & 55.62541 \\
\hline
\end{tabular}




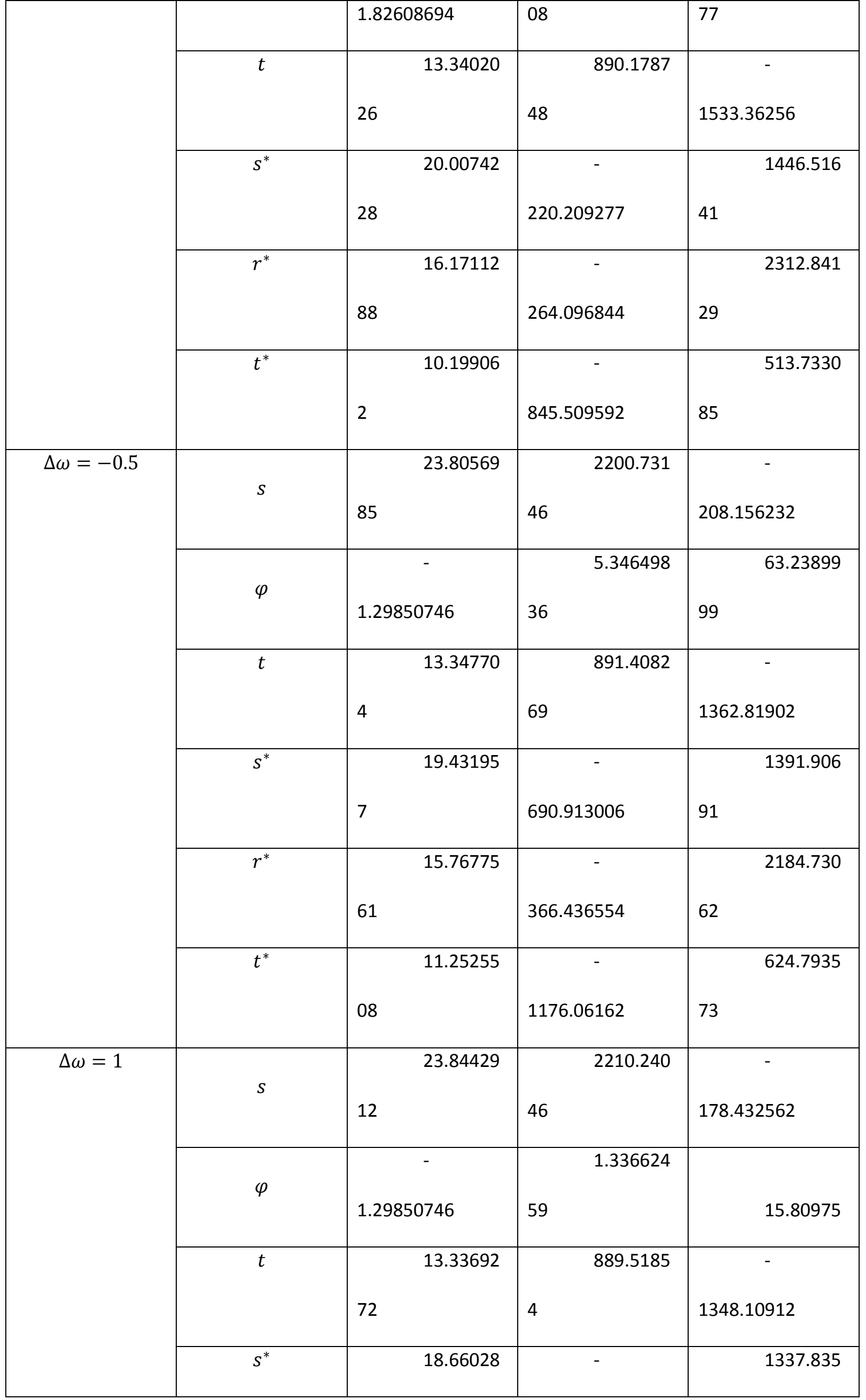




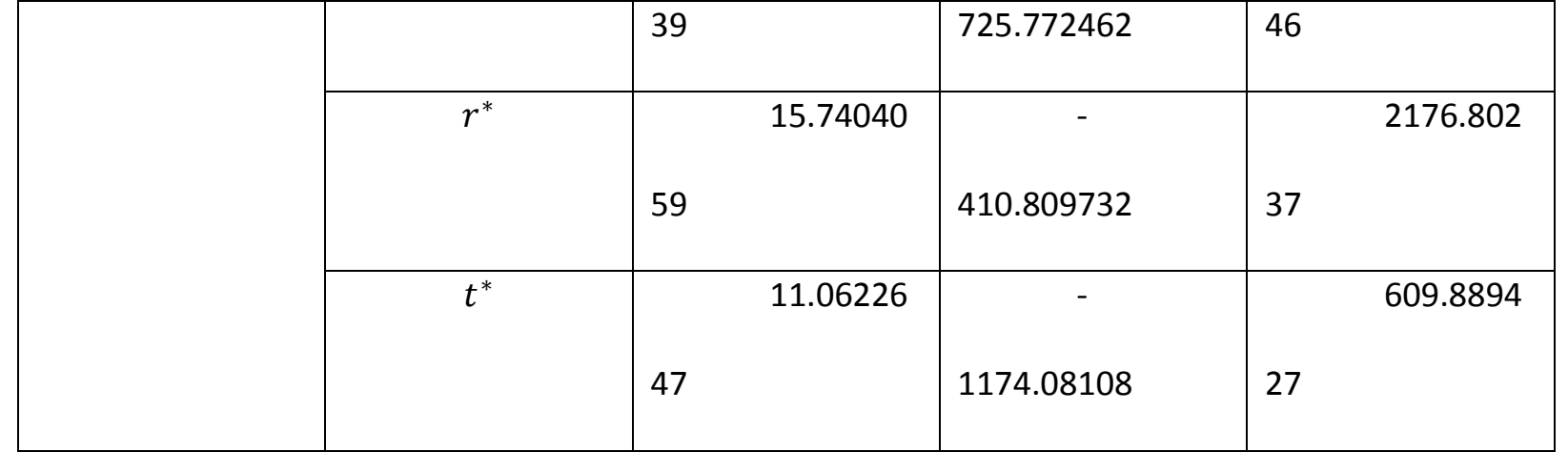

Source: author.

Note: $\quad a=50, a^{*}=40, c(\bar{\mu})=6, c^{*}\left(\underline{\mu}^{*}\right)=9, c^{*}\left(\bar{\mu}^{*}\right)=3, g=g^{*}=1, \theta=5, \omega=1, i=$ $0.1, v^{*}=10, \lambda=9$. (a) Since the Southern firm's marginal cost depends on the public R\&D investment, we study the case where the parameter $\lambda$ varies.

\section{General Forms for Demand Functions under Bertrand Competition}

Using general forms, we have the following reaction functions for the Northern firm: $p_{n}\left(p_{n}^{*}\right)=c-x / x_{p_{n}}, p_{s}\left(p_{s}^{*}\right)=c-x^{*} / x_{p_{s}}^{*}$. Then, the Northern firm's maximum profit is given by: $\pi\left(\hat{p}_{n}, \hat{p}_{s}\right)=-x_{p_{n}}\left(\hat{p}_{n}-c\right)^{2}-x_{p_{s}}\left(\hat{p}_{s}-c\right)^{2}$.

We make the assumption that the second order conditions are verified: $\pi_{p_{n} p_{n}}<0$, $\pi_{p_{s} p_{s}}<0, \pi_{p_{n}^{*} p_{n}^{*}}^{*}<0, \pi_{p_{s}^{*} p_{s}^{*}}^{*}<0$. However, cross effects are now positive: $\pi_{p_{n} p_{n}^{*}}>0, \pi_{p_{s} p_{s}^{*}}>0$ $\pi_{p_{n}^{*} p_{n}}^{*}>0, \pi_{p_{s}^{*} p_{s}}^{*}>0$. Own effects remain stronger than cross effects. Stability condition is also verified on each market under Bertrand competition: $B_{n}=\pi_{p_{n} p_{n}} \pi_{p_{n}^{*} p_{n}^{*}}^{*}-\pi_{p_{n} p_{n}^{*}} \pi_{p_{n}^{*} p_{n}}^{*}>0$, $B_{s}=\pi_{p_{s} p_{s}} \pi_{p_{s}^{*} p_{s}^{*}}^{*}-\pi_{p_{s} p_{s}^{*}} \pi_{p_{s}^{*} p_{s}}^{*}>0$

We have:

$$
\begin{aligned}
& \frac{\mathrm{d} \pi}{\mathrm{d} c}=x_{p_{n}}\left(\hat{p}_{n}-c\right)\left(1-\frac{\pi_{p_{n} p_{n}^{*}} \pi_{p_{n}^{*} p_{n}}^{*}}{B_{n}}\right)+x_{p_{s}}^{*}\left(\hat{p}_{s}-c\right)\left(1-\frac{\pi_{p_{s} p_{s}^{*}} \pi_{p_{S}^{*}}^{*} p_{s}}{B_{S}}\right)<0 \\
& \frac{\mathrm{d} \pi}{\mathrm{d} c^{*}}=x_{p_{n}}\left(\hat{p}_{n}-c\right) \frac{\pi_{p_{n} p_{n} \pi_{p_{n} p_{n}^{*}}}}{B_{n}}+x_{p_{s}}\left(\hat{p}_{s}-c\right) \frac{\pi_{p_{s} p_{s} \pi_{p_{s} p_{S}^{*}}}}{B_{S}}>0
\end{aligned}
$$

Let us study the impact of the Southern firm's marginal cost on the two previous expressions. Under linear demand functions, each second order term is null. Then, the only terms that depend on $c^{*}$ are $\hat{p}_{n}$ and $\hat{p}_{s}$. Furthermore, each price increases with each marginal cost. Then, the negative (positive) effect of the Northern (Southern) firm's marginal cost is stronger when the Southern firm's marginal cost increases. But under nonlinear demand functions, the results are unknown owing to the impact on second order terms. 
D. Numerical Simulations For The Welfare Analysis Under Bertrand Competition

Table 5 - Optimal Policy Instruments When Parameters Vary Under Bertrand Competition

\begin{tabular}{|c|c|c|c|c|}
\hline & $\begin{array}{l}\text { Instrume } \\
\text { nt }\end{array}$ & $\begin{array}{l}\text { Optimal } \\
\text { Value }\end{array}$ & $\Delta \mathrm{W}$ & $\Delta \mathrm{W}^{*}$ \\
\hline \multirow[t]{6}{*}{$\Delta a^{*}=10$} & $S$ & $\begin{aligned} & 4.454674 \\
55 & \end{aligned}$ & 150.7247 & $\begin{array}{c}- \\
120.850388\end{array}$ \\
\hline & $\varphi$ & $\begin{array}{c}- \\
1.51082255\end{array}$ & $\begin{array}{l}3.188862 \\
55\end{array}$ & $\begin{array}{ll} & 62.67308 \\
72 & \end{array}$ \\
\hline & $t$ & $\begin{array}{l}19.50399 \\
05\end{array}$ & $\begin{array}{l}2519.494 \\
5\end{array}$ & $\begin{array}{c}- \\
3016.77033\end{array}$ \\
\hline & $s^{*}$ & $\begin{array}{ll} & 3.410883 \\
93 & \end{array}$ & $\begin{array}{c}- \\
235.606622\end{array}$ & $\begin{array}{r}88.35035 \\
17\end{array}$ \\
\hline & $r^{*}$ & $\begin{array}{l}19.53027 \\
8\end{array}$ & $\begin{array}{c}- \\
325.173007\end{array}$ & $\begin{array}{r}3453.640 \\
53\end{array}$ \\
\hline & $t^{*}$ & $\begin{aligned} & 19.98638 \\
51 & \end{aligned}$ & $\begin{array}{c}- \\
3700.37189\end{array}$ & $\begin{array}{r}2633.872 \\
51\end{array}$ \\
\hline \multirow[t]{6}{*}{$\Delta a^{*}=20$} & $S$ & $\begin{array}{ll} & 4.164814 \\
12 & \end{array}$ & 131.7687 & $\begin{array}{r}- \\
97.685287\end{array}$ \\
\hline & $\varphi$ & $\begin{array}{c}- \\
1.17245245\end{array}$ & $\begin{array}{l}2.361659 \\
5\end{array}$ & 49.36387 \\
\hline & $t$ & $\begin{array}{ll} & 19.50294 \\
82 & \end{array}$ & $\begin{array}{ll} & 2519.162 \\
74 & \end{array}$ & $\begin{array}{c}- \\
3015.45629\end{array}$ \\
\hline & $s^{*}$ & 4.576967 & $\begin{array}{c}- \\
381.387269\end{array}$ & 159.1073 \\
\hline & $r^{*}$ & 20.73277 & $\begin{array}{c}- \\
427.239808\end{array}$ & 3935.783 \\
\hline & $t^{*}$ & 24.68548 & $\begin{array}{c}- \\
5602.05204\end{array}$ & 4019.660 \\
\hline
\end{tabular}




\begin{tabular}{|c|c|c|c|c|}
\hline \multirow[t]{6}{*}{$\Delta c^{*}\left(\underline{\mu}^{*}\right)=-3$} & $S$ & 4.320970 & 141.7609 & \begin{tabular}{|c|}
- \\
236.213747
\end{tabular} \\
\hline & $\varphi$ & \begin{tabular}{|c|}
- \\
2.89216977 \\
\end{tabular} & 6.158928 & $\begin{array}{|ll|} & 126.7041 \\
26 & \\
\end{array}$ \\
\hline & $t$ & \begin{tabular}{|l} 
\\
\\
85
\end{tabular} & $\begin{array}{ll} & 2753.949 \\
23 & \end{array}$ & $\begin{array}{c}- \\
3610.11701\end{array}$ \\
\hline & $s^{*}$ & 2.933457 & $\begin{array}{c}- \\
100.551223\end{array}$ & 65.32974 \\
\hline & $r^{*}(\mathrm{a})$ & $\begin{array}{ll} & 12.63564 \\
99 & \end{array}$ & $\begin{array}{c}- \\
71.2465623\end{array}$ & 1511.025 \\
\hline & $t^{*}$ & $\begin{array}{ll} & 15.82568 \\
61 & \end{array}$ & $\begin{array}{c}- \\
2112.76711\end{array}$ & $\begin{array}{ll} & 1649.493 \\
97 & \end{array}$ \\
\hline \multirow[t]{6}{*}{$\Delta c^{*}\left(\underline{\mu}^{*}\right)=3$} & $S$ & 5.166464 & 202.7141 & $\begin{array}{c}- \\
36.1273328\end{array}$ \\
\hline & $\varphi$ & $\begin{array}{c}- \\
1.62196153\end{array}$ & 3.453165 & 61.12948 \\
\hline & $t$ & $\begin{array}{ll} & 18.61943 \\
61 & \end{array}$ & $\begin{array}{ll} & 2296.219 \\
15 & \end{array}$ & $\begin{array}{r}- \\
2466.1469\end{array}$ \\
\hline & $s^{*}$ & 1.557754 & $\begin{array}{c}- \\
117.350807\end{array}$ & 18.42588 \\
\hline & $r^{*}(\mathrm{a})$ & 22.54911 & $\begin{array}{r}- \\
433.181735\end{array}$ & 4262.329 \\
\hline & $t^{*}$ & 14.74810 & $\begin{array}{c}- \\
2259.16204\end{array}$ & 1434.330 \\
\hline \multirow[t]{2}{*}{$\Delta c(\bar{\mu})=-3$} & $S$ & $\begin{array}{ll} & 5.432101 \\
31 & \end{array}$ & 224.1331 & $\begin{array}{c}- \\
54.2325001\end{array}$ \\
\hline & $\varphi$ & $\begin{array}{r}- \\
1.2926179\end{array}$ & $\begin{array}{ll} & 2.658768 \\
26 & \end{array}$ & 45.52921 \\
\hline
\end{tabular}




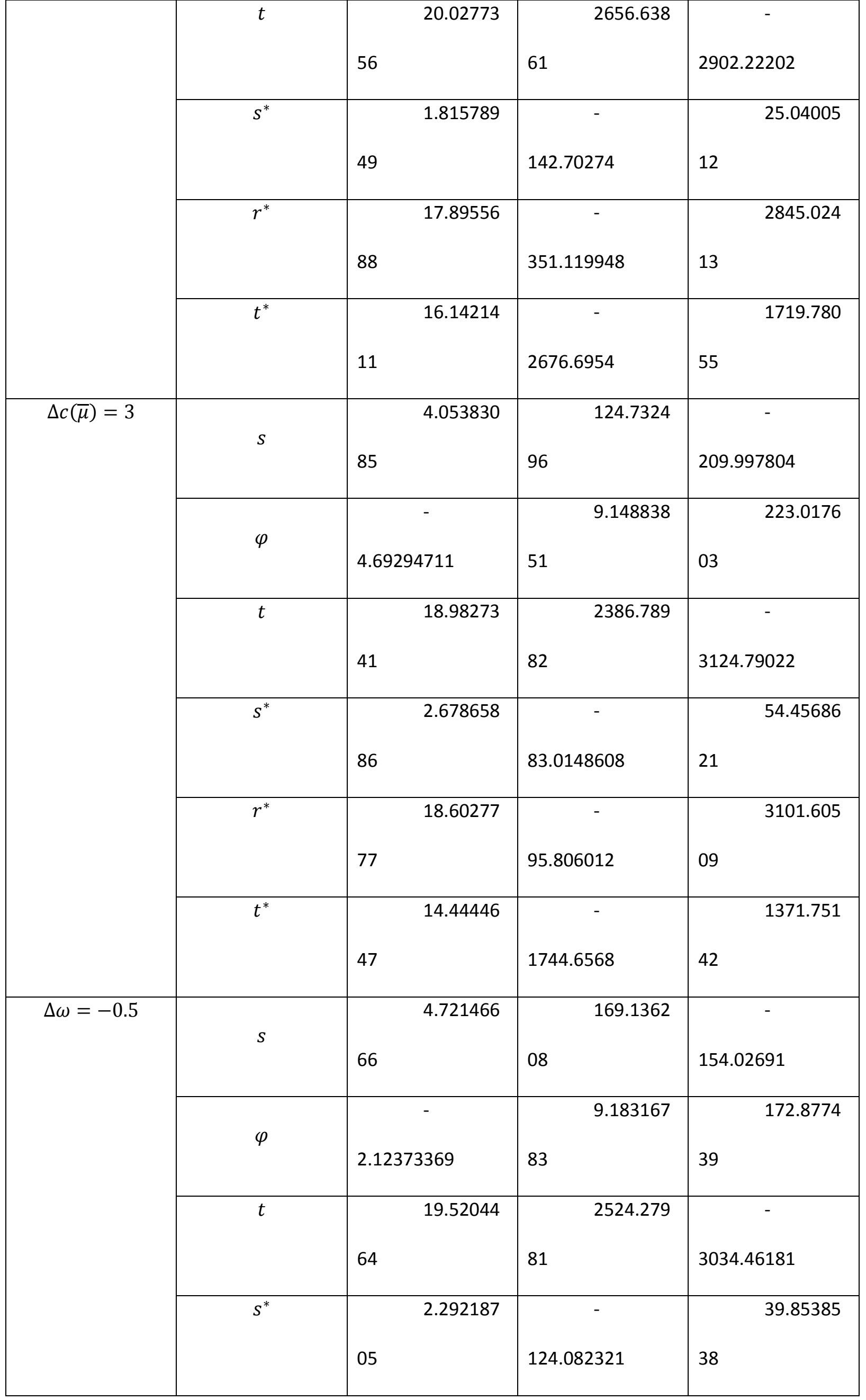




\section{ReCent LAREFI Working PAPers}

For earlier LAREFI Working Papers, please go to http://lare-efi.org.u-bordeaux4.fr All Discussion Papers can be downloaded free of charge

2015-001 International trade and structural change : a dynamic model of weak sustainability Louis Dupuy

2014-006 Basel III and SME access to credit : Evidence from France Thomas Humblot 2014-005 Source and host country volatility and FDI: A gravity analysis of European investment to Middle East and North Africa Dalila Nicet-Chena f, Eric Rougier

2014-004 Determinants of Global Liquidity Dynamics:a FAVAR approach Marie-Louise Djigbenou

2014-003 Finance and international trade : A review of the literature Anne-Gaël Vaubourg 2014-002 Chocs extérieurs et régimes monétaires en Asie du Sud-Est : une analyse DSGE Ibrahima Sangaré

2014-001 In Search of the Banking Regulator amid U.S. Financial Reforms of the 1930s Dominique Lacoue-Labarthe 2013-006 Contagion des crises de 1997 et 2008 en ASEAN+3 : un modèle VAR structurel Marine Coupaud 2013-005 Quels sont les enseignements de l'histoire du fédéralisme américain pour la zone euro actuelle? Dominique Jacob 